\title{
Young rift kinematics in the Tadjoura rift, western Gulf of Aden, Republic of Djibouti
}

\author{
Mohamed A. Daoud, ${ }^{1,2}$ Bernard Le Gall, ${ }^{2}$ René C. Maury, ${ }^{2}$ Joël Rolet, ${ }^{2}$ Philippe Huchon, ${ }^{3}$ \\ and Hervé Guillou ${ }^{4}$
}

Received 23 September 2009; revised 30 June 2010; accepted 14 September 2010; published 11 January 2011.

[1] The Tadjoura rift forms the westernmost edge of the westerly propagating Sheba ridge, between Arabia and Somalia, as it enters into the Afar depression. From structural and remote sensing data sets, the Tadjoura rift is interpreted as an asymmetrical south facing half-graben, about $40 \mathrm{~km}$ wide, dominated by a large boundary fault zone to the north. It is partially filled up by the 1-3 Myr old Gulf Basalts which onlapped the older Somali Basalts along its shallower southern flexural margin. The major and trace element analysis of 78 young onshore lavas allows us to distinguish and map four distinct basaltic types, namely the Gulf, Somali, Goumarre, and Hayyabley Basalts. These results, together with radiometric age data, lead us to propose a revised volcano-stratigraphic sketch of the two exposed Tadjoura rift margins and to discriminate and date several distinct fault networks of this oblique rift. Morphological and statistical analyses of onshore extensional fault populations show marked changes in structural styles along-strike, in a direction parallel to the rift axis. These major fault disturbances are assigned to the arrest of axial fault tip propagation against preexisting discontinuities in the NS-oriented Arta transverse zone. According to our model, the sinistral jump of rifting into the Asal-Ghoubbet rift segment results from structural inheritance, in contrast with the en échelon or transform mechanism of propagation that prevailed along the entire length of the Gulf of Aden extensional system. Citation: Daoud, M. A., B. Le Gall, R. C. Maury, J. Rolet, P. Huchon, and H. Guillou (2011), Young rift kinematics in the Tadjoura rift, western Gulf of Aden, Republic of Djibouti, Tectonics, 30, TC1002, doi:10.1029/2009TC002614.

\section{Introduction}

[2] The overall architecture of rift/ridge systems is controlled by several physical parameters which interact at

\footnotetext{
${ }^{1}$ Institut des Sciences de la Terre, Centre d'Études et de Recherches de Djibouti, Djibouti Ville, Djibouti.

${ }^{2}$ Université Européenne de Bretagne, Université de Brest, CNRS, UMR 6538 Domaines Océaniques, IUEM, Plouzané, France.

${ }^{3}$ UPMC Université de Paris 6, CNRS, UMR 7193, ISTeP, Paris, France.

${ }^{4}$ UMR 1572, LSCE/CEA-CNRS, Domaine du CNRS, Gif-sur-Yvette, France.

Copyright 2011 by the American Geophysical Union. 0278-7407/11/2009TC002614
}

various scales of times and space, and usually lead to intricate geometrical configurations. The large-scale spatial architecture of a propagating rift is known to depend merely on the absolute motions of the bounding plates, and on major lateral discontinuities in the strength of either the upper crust (e.g., inherited structures), or the lower crust (e.g., partial melt zones) [Ziegler and Cloetingh, 2004; Wijns et al., 2005]. At a smaller scale, the segmentation of the spreading axis within the rifted zone itself is commonly assigned to (1) its obliquity to the extension direction and (2) the angle between the axis of individual rift segments and the general trend of the rifted zone [Abelson and Agnon, 1997]. The resulting complex multiscale rift architecture is typically expressed along the Sheba westerly propagating rift-drift system (Eastern Afar) by two nearly orthogonal first-order arms that, in turn, display specific segmented axial patterns (Figures 1a and 1b). Along most of its EW trending path, the Sheba oceanic ridge is systematically offset to the southwest. This offset occurs through either a left stepping ridge-transform network (up to the Shukra El Sheikh discontinuity [e.g., Manighetti et al., 1997]) or oblique transfer zones with onlapping fault networks, up to the Tadjoura rift (TR) to the west (Figure 1b) [Cochran, 1981; Tamsett and Searle, 1988; Manighetti et al., 1997; Dauteuil et al., 2001]. There, the nearly EW trending axis veers abruptly counterclockwise into the $\mathrm{N} 120^{\circ} \mathrm{E}$-oriented Ghoubbet rift, which is part of a submeridian, and partly emerged, rifted zone encompassing to the north the Asal and Manda Inakir en échelon subrifts (Figure 1b) [Manighetti et al., 1998]. The structural link between the two suborthogonal rift arms in the TR has been variously interpreted, and assigned to either a largescale dextral fault zone, in the prolongation of the NE-SW Maskali transform fault (Figure 1b) [Ruegg et al., 1980; Arthaud et al., 1980; Gaulier and Huchon, 1991], or to an overlapping fault zone enclosing a network of en échelon structures (Figure 1d) [Manighetti et al., 1997].

[3] The main goal of the present work is to address the mechanism of strain transfer between the Tadjoura and Ghoubbet rifts, with emphasis on the structure of the TR. Our study integrates (1) available seismic and bathymetric offshore data; (2) sampling, geochemical analysis and $\mathrm{K} / \mathrm{Ar}$ dating of young basalts from the Djibouti Plain, which lead us to propose a new geological map of the southern part of the TR; and (3) structural analyses based on field studies and remote sensing interpretation. These new data allow us to demonstrate that the TR typically displays a half-graben structure, which recorded a progressive shift of strain toward its inner part during the last $3 \mathrm{Myr}$. In addition, we propose 


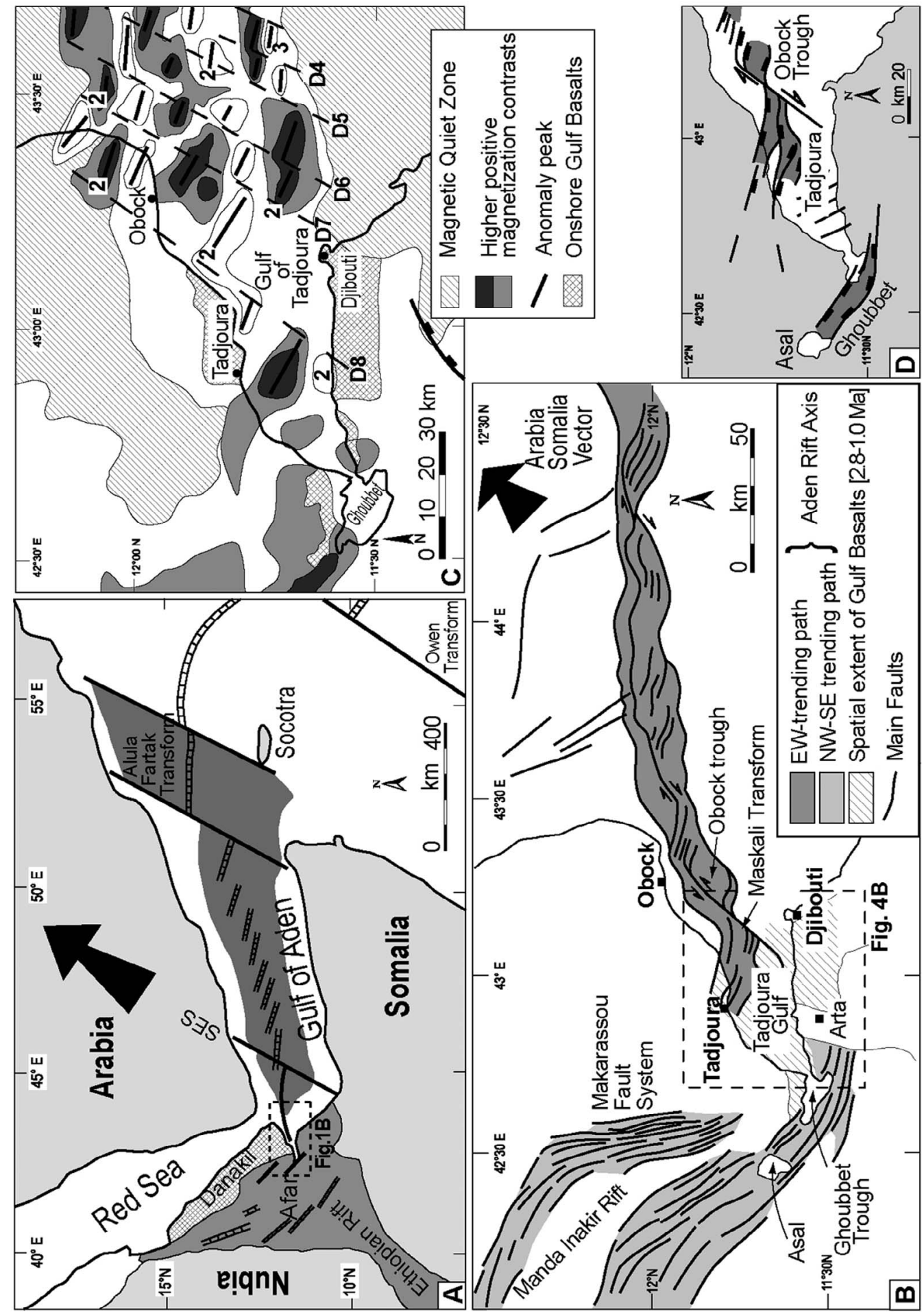

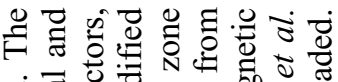

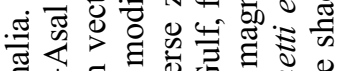

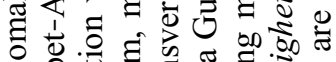
ڤ

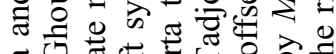

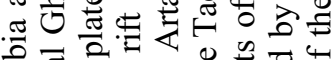
쥼

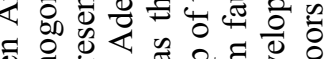

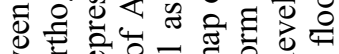

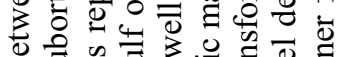

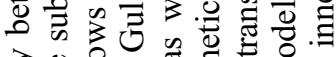

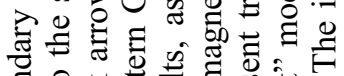

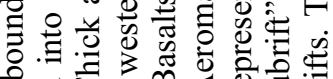
F

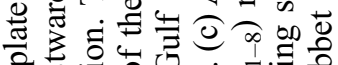
च

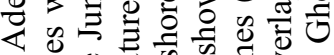

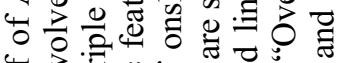

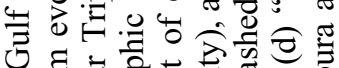

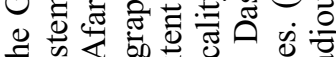

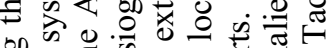

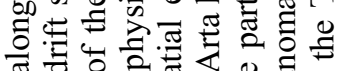
ब

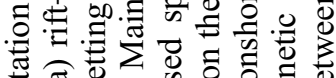

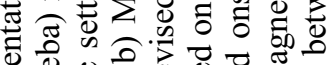

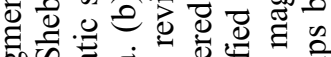

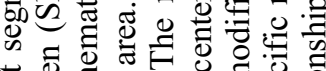

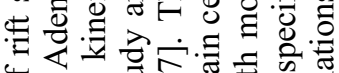

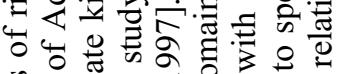

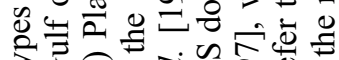

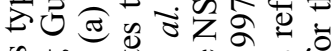
号.

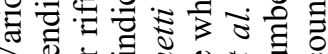

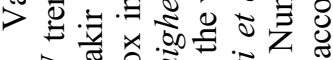

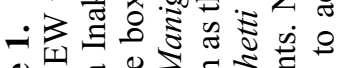

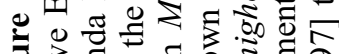

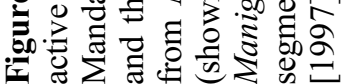


Table 1. Chemical Compositions of Representative Whole Rock Samples of Gulf, Goumarre, Somali, and Hayyabley Basalts ${ }^{\mathrm{a}}$

\begin{tabular}{|c|c|c|c|c|c|c|c|c|c|c|c|c|c|c|c|}
\hline & \multicolumn{3}{|c|}{$\begin{array}{c}\text { Gulf Basalts } \\
\text { (Northern margin) }\end{array}$} & \multicolumn{4}{|c|}{$\begin{array}{c}\text { Gulf Basalts } \\
\text { (Southern margin) }\end{array}$} & \multicolumn{3}{|c|}{ Goumarre Basalts } & \multicolumn{4}{|c|}{ Somali Basalts } & \multirow{2}{*}{$\begin{array}{c}\text { Hayyabley } \\
\text { Basalts }\end{array}$} \\
\hline & $\operatorname{dj} 18 / 06$ & Ji & 06 & ד & d & 00 & b & 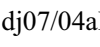 & & & $03 /$ & di30/05 & ii1 & $9 / 04 b$ & \\
\hline \multicolumn{16}{|c|}{ Major Element Oxides (wt \%) } \\
\hline $\mathrm{SiO}_{2}$ & 46.30 & 46.20 & 45.90 & 46.10 & 47.40 & 47.60 & 46.50 & 47.00 & 48.00 & 48.00 & 49.20 & 48.20 & 49.86 & 50.10 & 47.15 \\
\hline $\mathrm{TiO}_{2}$ & 2.92 & 2.71 & 1.98 & 2.46 & 2.65 & 2.78 & 2.96 & 3.72 & 3.62 & 3.84 & 3.32 & 3.42 & 2.88 & 2.88 & 0.93 \\
\hline $\mathrm{Al}_{2} \mathrm{O}_{3}$ & 14.35 & 15.35 & 15.35 & 14.55 & 13.87 & 14.15 & 14.20 & 13.34 & 13.48 & 13.25 & 13.00 & 13.36 & 13.85 & 13.50 & 16.53 \\
\hline $\mathrm{Fe}_{2} \mathrm{O}_{3} *$ & 15.40 & 14.50 & 14.20 & 14.62 & 16.10 & 15.95 & 16.68 & 15.00 & 15.25 & 15.50 & 15.10 & 16.15 & 14.50 & 14.50 & 10.35 \\
\hline $\mathrm{MnO}$ & 0.22 & 0.21 & 0.21 & 0.21 & 0.23 & 0.24 & 0.24 & 0.22 & 0.23 & 0.24 & 0.22 & 0.25 & 0.22 & 0.22 & 0.17 \\
\hline $\mathrm{MgO}$ & 8.20 & 7.65 & 6.75 & 8.50 & 6.05 & 6.10 & 6.24 & 5.77 & 5.17 & 4.95 & 4.74 & 4.89 & 4.82 & 4.92 & 9.45 \\
\hline $\mathrm{CaO}$ & 10.00 & 10.45 & 11.00 & 10.45 & 10.05 & 9.80 & 9.74 & 10.45 & 10.00 & 9.60 & 9.30 & 9.50 & 9.24 & 9.15 & 12.9 \\
\hline $\mathrm{Na}_{2} \mathrm{O}$ & 2.66 & 2.67 & 2.35 & 2.53 & 2.71 & 2.77 & 2.71 & 2.86 & 3.03 & 3.13 & 2.90 & 3.04 & 3.14 & 3.22 & 1.99 \\
\hline $\mathrm{K}_{2} \mathrm{O}$ & 0.47 & 0.34 & 0.23 & 0.34 & 0.53 & 0.54 & 0.44 & 0.71 & 0.81 & 0.75 & 0.86 & 0.72 & 0.76 & 0.67 & 0.08 \\
\hline $\mathrm{P}_{2} \mathrm{O}_{5}$ & 0.42 & 0.30 & 0.23 & 0.34 & 0.38 & 0.34 & 0.38 & 0.54 & 0.59 & 0.53 & 0.62 & 0.56 & 0.41 & 0.40 & 0.07 \\
\hline LOI & -0.83 & -0.42 & 1.54 & -0.28 & -0.50 & -0.46 & -0.73 & -0.38 & -0.31 & -0.48 & 0.41 & -0.25 & 0.05 & -0.12 & 0.46 \\
\hline Total & 100.11 & 99.96 & 99.74 & 99.82 & 99.47 & 99.81 & 99.36 & 99.23 & 99.87 & 99.31 & 99.61 & 99.84 & 99.72 & 99.44 & 100.08 \\
\hline \multicolumn{16}{|c|}{ Trace Elements (ppm) } \\
\hline $\mathrm{Rb}$ & 6.90 & 5.20 & 2.70 & 5.00 & 10.20 & 6.80 & 8.30 & 13.80 & 16.00 & 14.90 & 18.00 & 11.80 & 10.30 & 17.30 & 1.05 \\
\hline $\mathrm{Sr}$ & 320.00 & 393.00 & 317.00 & 315.00 & 262.00 & 264.00 & 266.00 & 378.00 & 378.00 & 810.00 & 318.00 & 330.00 & 320.00 & 317.00 & 154.00 \\
\hline $\mathrm{Ba}$ & 168.00 & 138.00 & 119.00 & 130.00 & 208.00 & 158.00 & 155.00 & 210.00 & 223.00 & 305.00 & 270.00 & 290.00 & 220.00 & 212.00 & 34.00 \\
\hline $\mathrm{Sc}$ & 35.00 & 31.50 & 37.50 & 35.00 & 39.00 & 38.00 & 39.00 & 38.00 & 33.00 & 32.00 & 34.00 & 35.5 & 34.5 & 36.00 & 45.00 \\
\hline $\mathrm{V}$ & 380.00 & 350.00 & 337.00 & 365.00 & 405.00 & 395.00 & 425.00 & 460.00 & 400.00 & 465.00 & 405.00 & 398.00 & 388.00 & 395.00 & 285.00 \\
\hline $\mathrm{Cr}$ & 287.00 & 207.00 & 311.00 & 320.00 & 94.00 & 89.00 & 69.00 & 130.00 & 44.00 & 28.00 & 28.00 & 22.00 & 29.00 & 29.00 & 380.00 \\
\hline $\mathrm{Co}$ & 56.00 & 53.00 & 57.00 & 58.00 & 56.00 & 51.00 & 54.00 & 44.00 & 43.00 & 43.00 & 44.00 & 43.00 & 44.00 & 43.00 & 51.00 \\
\hline $\mathrm{Ni}$ & 150.00 & 135.00 & 153.00 & 175.00 & 79.00 & 71.00 & 78.00 & 76.00 & 48.00 & 35.00 & 38.00 & 24.50 & 42.00 & 41.00 & 198.00 \\
\hline $\mathrm{Y}$ & 34.50 & 29.50 & 26.50 & 33.00 & 42.00 & 42.0 & 42.50 & 42.50 & 45.00 & 44.00 & 48.50 & 45.00 & 42.00 & 41.50 & 20.50 \\
\hline $\mathrm{Zr}$ & 190.00 & 153.00 & 122.00 & 160.00 & 200.00 & 204.00 & 195.00 & 275.00 & 280.00 & 293.00 & 280.00 & 253.00 & 256.00 & 264.00 & 48.00 \\
\hline $\mathrm{Nb}$ & 25.00 & 20.20 & 13.00 & 18.00 & 23.00 & 25.00 & 22.50 & 39.50 & 41.00 & 45.00 & 36.50 & 32.00 & 31.00 & 32.00 & 2.70 \\
\hline $\mathrm{La}$ & 19.50 & 16.30 & 13.00 & 15.40 & 20.00 & 21.50 & 20.00 & 30.50 & 34.00 & 33.50 & 30.00 & 28.00 & 27.50 & 27.50 & 2.60 \\
\hline $\mathrm{Ce}$ & 44.00 & 39.00 & 31.00 & 36.00 & 46.00 & 49.00 & 46.00 & 68.00 & 76.00 & 74.00 & 69.00 & 63.00 & 61.00 & 62.00 & 7.1 \\
\hline $\mathrm{Nd}$ & 28.00 & 24.50 & 20.00 & 22.50 & 27.50 & 29.00 & 28.00 & 41.00 & 45.00 & 44.00 & 41.5 & 37.50 & 36.00 & 35.50 & 5.3 \\
\hline $\mathrm{Sm}$ & 6.70 & 5.85 & 4.40 & 5.70 & 6.90 & 6.80 & 7.10 & 9.10 & 9.70 & 9.50 & 9.60 & 8.50 & 8.10 & 8.25 & 2.00 \\
\hline $\mathrm{Eu}$ & 2.2 & 2.01 & 1.68 & 1.96 & 2.25 & 2.22 & 2.3 & 2.87 & 3.12 & 3.01 & 3.02 & 2.87 & 2.56 & 2.54 & 0.8 \\
\hline $\mathrm{Gd}$ & 6.7 & 5.9 & 5.00 & 6.10 & 7.15 & 7.6 & 8.00 & 8.9 & 10.00 & 9.50 & 10.00 & 9.40 & 8.60 & 8.20 & 2.30 \\
\hline Dy & 6.35 & 5.10 & 4.50 & 6.00 & 7.25 & 7.40 & 7.40 & 8.00 & 8.50 & 8.30 & 9.00 & 7.90 & 8.00 & 7.85 & 3.30 \\
\hline $\mathrm{Er}$ & 3.30 & 2.70 & 2.50 & 3.10 & 4.00 & 4.00 & 4.10 & 4.00 & 4.40 & 4.10 & 4.70 & 4.20 & 4.00 & 4.00 & 2.10 \\
\hline $\mathrm{Yb}$ & 3.05 & 2.55 & 2.29 & 2.85 & 3.73 & 3.80 & 3.80 & 3.47 & 3.80 & 3.62 & 4.00 & 3.90 & 3.68 & 3.66 & 2.18 \\
\hline Th & 1.50 & 0.80 & 0.80 & 1.02 & 2.55 & 2.55 & 1.85 & 3.00 & 3.40 & 3.40 & 3.00 & 2.75 & 3.20 & 3.45 & 0.10 \\
\hline
\end{tabular}

${ }^{\mathrm{a}}$ Sample locations are shown in the auxiliary material, and analytical methods are discussed in the text.

that submeridian structural discontinuities, emplaced at an early stage of rifting in the Arta transverse zone (Figure 1b) may have locked the westerly propagation of extension in the TR, hence causing the jump of rift axis southwestward into the Ghoubbet subrift.

\section{Methodology}

[4] The 3-D structure of the TR was first investigated in map view, and along selected cross sections, by merging onshore geology with existing offshore data, which include bathymetric maps [Audin, 1999; Dauteuil et al., 2001] and analog, single channel seismic reflection profiles acquired during the TADJOURADEN cruise in 1995. The offshore fault pattern extracted from the bathymetric contour maps has a relatively low horizontal resolution $(150 \mathrm{~m})$ which does not permit quantitative comparisons with onshore fault parameters. Therefore, it was only used here to get an overview of the entire TR. The deep geometry of a number of offshore faults has been determined using the TADJOURADEN seismic reflection profiles. Onshore field studies have been focused on poorly investigated areas from the southern margin of the TR, e.g., the Djibouti Plain, and the Arta transverse zone, where $>3$ Myr old volcanics are widely exposed (Figure 1b). Quantitative analysis of fault parameters (length, azimuth, spacing) was conducted on fault populations extracted from ASTER satellite images (lateral resolution $15 \mathrm{~m}$ ) and corresponding digital elevation models (vertical resolution $7 \mathrm{~m}$ ). Estimates of vertical displacement along each fault were derived from fault scarp geometry. Seriated topographic profiles across each individual fault scarp gave the maximum value of displacement at the surface. When the top surface of the footwall uplifted block was degraded by erosion, the summit-level envelope was used as a surface marker to restore the initial footwall geometry. In any case, vertical throws represent minimum estimates which do not account for possible fault displacement at depth. Markers for sense of displacement (striations) are generally not observed along exposed fault surfaces within basalts, hence precluding any accurate stress reconstructions to be performed. The age pattern of faulting within the TR was established from crosscutting relationships of faults with dated volcanic and sedimentary sequences. The structure of the adjoining Ghoubbet rift is 
Table 2. New K-Ar Datings of Two Gulf Basalt Samples From the Wea Paleo-Valley ${ }^{\mathrm{a}}$

\begin{tabular}{|c|c|c|c|c|c|c|}
\hline \multirow[b]{2}{*}{ Experiment } & \multicolumn{4}{|c|}{ Split } & \multicolumn{2}{|c|}{ Weighted Mean } \\
\hline & $\mathrm{K}(\mathrm{wt} \%) \pm 1 \sigma$ & Mass molten $(\mathrm{g})$ & ${ }^{40} \mathrm{Ar}^{*}(\%)$ & $\begin{array}{c}{ }^{40} \mathrm{Ar}^{*} 10^{-13} \\
(\mathrm{~mol} / \mathrm{g}) \pm 1 \sigma\end{array}$ & $\begin{array}{l}{ }^{40} \mathrm{Ar}^{*} 10^{-13} \\
(\mathrm{~mol} / \mathrm{g}) \pm 1 \sigma\end{array}$ & $\begin{array}{c}\text { Age } \\
(\mathrm{Myr}) \pm 2 \sigma\end{array}$ \\
\hline $\mathrm{dj} 43 / 04 \mathrm{~b} 7454$ & $0.371 \pm 0.004$ & 1.07191 & 2.434 & $7.003 \pm 0.106$ & & \\
\hline 7470 & $\langle\ldots \ldots \ldots \ldots \ldots »$ & 1.00241 & 3.093 & $7.020 \pm 0.105$ & $7.012 \pm 0.008$ & $1.09 \pm 0.03$ \\
\hline dj38/05 7257 & $0.332 \pm 0.003$ & 1.09347 & 2.153 & $6.949 \pm 0.109$ & & \\
\hline 7273 & $\langle\ldots \ldots \ldots \ldots \ldots$ & 1.02438 & 3.088 & $6.796 \pm 0.122$ & $6.882 \pm 0.081$ & $1.19 \pm 0.04$ \\
\hline
\end{tabular}

${ }^{a}$ Sample locations are shown in Figure 2a, and analytical methods are discussed in the text.

only briefly discussed here, with reference to published works [Audin et al., 2001].

[5] Geochemical analyses (major and trace elements) and radiometric dating ( $\mathrm{K} / \mathrm{Ar}$ method) have been focused on poorly known mafic volcanics from the Djibouti Plain, with the aim of identifying several basaltic units and mapping them. Major and trace element data on bulk rocks (Table 1) were obtained by Inductively Coupled Plasma-Atomic Emission Spectrometry (ICP-AES) at IUEM (Institut Universitaire Européen de la Mer), Plouzané. International standards were used for calibration tests (ACE, BEN, JB-2, $\mathrm{PM}-\mathrm{S}$ and WS-E). Rb was measured by flame emission spectroscopy. Relative standard deviations are $\pm 1 \%$ for $\mathrm{SiO}_{2}$, and $\pm 2 \%$ for other major elements except $\mathrm{P}_{2} \mathrm{O}_{5}$ and $\mathrm{MnO}$ $( \pm 0.01 \%)$, and approximately $5 \%$ for trace elements. The analytical techniques are described by Cotten et al. [1995]. Ar isotopic compositions and $\mathrm{K}$ contents of two samples (Table 2) were measured at LSCE, Gif-sur-Yvette and IUEM, respectively. Ar analyses were performed using the unspiked technique procedures detailed by Yurtmen et al. [2002] and Guillou et al. [2004]. Ages were calculated using the constants recommended by Steiger and Jäger [1977].

\section{Spatial and Temporal Distribution of Synrift Volcanism in the Tadjoura Rift}

\subsection{General Rift Setting}

[6] The Sheba accretionary ridge within the Gulf of Aden forms, together with the Red Sea and the Ethiopian rift, one of the three diverging branches of the Afar Triple Junction (Figure 1a). According to magnetic anomaly data, midoceanic ridge segments and fracture zones initiated along its eastern part at 17-18 Myr [Leroy et al., 2004; d'Acremont et al., 2006], or possibly at $20 \mathrm{Myr}$ [Fournier et al., 2010], and then propagated westward, obliquely to the $\mathrm{N} 40^{\circ} \mathrm{E}$ direction of Arabia-Somalia plate separation [Cochran, 1981] (Figure 1a). Emplacement of incipient oceanic crust at the western tip of the Sheba ridge is recorded along the $\sim \mathrm{EW}$ trending Obock-Tadjoura Gulf by $<2$ Myr old paired magnetic anomalies (Figure 1c). The anomalies partly coincide with the 3-1 Myr Gulf basaltic series which floor the Tadjoura Gulf, and outcrop onshore in its northern (Tadjoura) and southern (Djibouti Plain) margins [Manighetti et al., 1997] (Figure 1b). The EWoriented TR-related structures intersect at high-angle older tectono-magmatic fabrics displaying a submeridian orientation in the Mabla (15-11 Myr), Somali (7.2-3.6 Myr), and Ribta (3.6 Myr) substratum series, emplaced at an earlier stage of rifting.
[7] The Gulf Basalts are a potentially accurate structural marker of the rift history recorded by the TR in the last $3 \mathrm{Myr}$, and it is therefore important to determine their spatial and temporal distribution for a better definition of the TR. That has been attempted by using new geochemical and age data set obtained on basaltic units in the Djibouti Plain, i.e., on the southern margin of the TR. Combined with previously published $\mathrm{K}-\mathrm{Ar}$ ages, this data set allows us to discriminate four recent basaltic units, i.e., the Gulf, Somali, Goumarre, and Hayyabley Basalts, hence allowing significant revision of the 2-D map structure of the TR (Figure $2 \mathrm{a}$ and Figure S1 in the auxiliary material). ${ }^{1}$ The two first units were already identified by previous authors [Richard, 1979; Gasse et al., 1983, 1985, 1986] from volcano-stratigraphic criteria. The various geographical subunits of the Gulf Basalts distinguished by these authors have, however, been grouped into a single volcanic unit because of their identical geochemical signatures. Gasse et al. [1983] also noted important chemical differences between the Hayyabley and Gulf Basalts. Finally, although they are younger than the Gulf and Somali Basalts which they crosscut, the Goumarre basalts were not recognized as a distinct type prior to this study.

\subsection{Geochemical Characteristics of the Tadjoura Rift Basalts}

\subsubsection{Sampling and Classification}

[8] Seventy eight mafic lavas have been analyzed for major and trace elements (see Table 1 for representative analyses). They include 21 samples from the Gulf Basalts in the Djibouti Plain, 10 from the same unit north of the Tadjoura Gulf, 22 from the Somali Basalts, 16 from the young volcanic cones and intrusions of the Goumarre Basalts, and finally 9 from the Hayyabley volcano. The locations of these samples are shown in the auxiliary material, except those of the Hayyabley Basalts which are given by Daoud et al. [2010]. In addition to this sample set, we have shown, as envelopes in Figures $3 a-3 d$, the fields of previously published analyses of (1) the Gulf Basalts (Initial Gulf Basalts) [Richard, 1979; Joron et al., 1980a; Vidal et al., 1991; Deniel et al., 1994], (2) the Asal Basalts [Richard, 1979; Joron et al., 1980b; Vidal et al., 1991; Deniel et al., 1994], and (3) offshore basalts dredged along the gulf axis [Barrat et al., 1990, 1993].

[9] All the collected samples are basalts, according to the total alkalies-silica (TAS) classification scheme of Le Bas

\footnotetext{
${ }^{1}$ Auxiliary materials are available in the HTML. doi:10.1029/ 2009TC002614.
} 

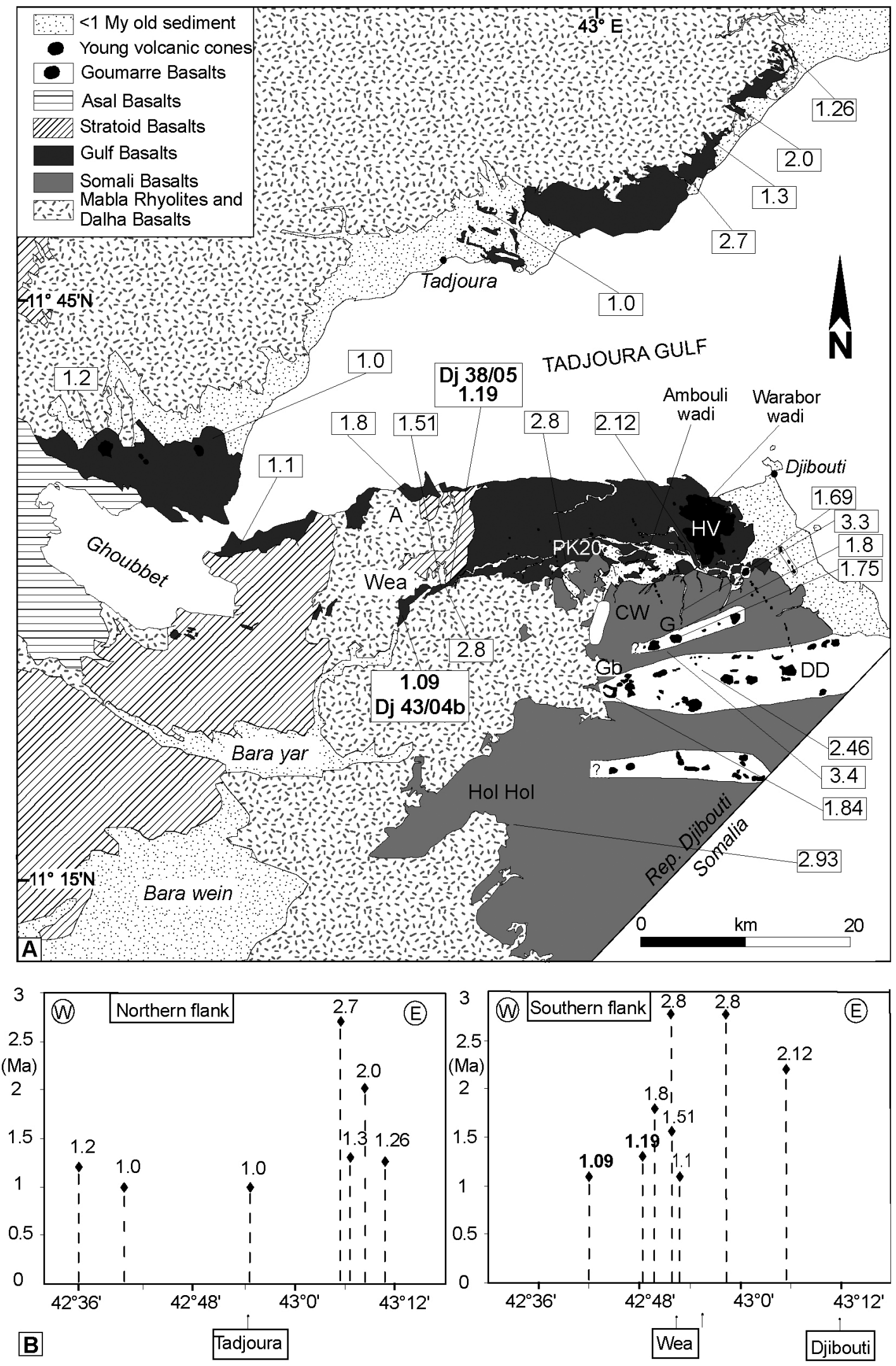

Figure 2 
et al. [1986]. In the TAS plot of Figure 3a, they lie on both sides of, but close to, the line separating the fields of subalkalic and alkalic basalts [Irvine and Baragar, 1971], with the exception of Hayyabley Basalts which are clearly subalkalic. The Gulf, Goumarre and Somali Basalts can therefore be considered as transitional basalts with a dominant tholeiitic tendency [Richard, 1979; Bizouard and Richard, 1980; Joron et al., 1980a, 1980b; Vidal et al., 1991; Deniel et al., 1994]. The various groups may be quite readily distinguished using the TAS plot (Figure 3a), which has been used, together with other major and trace element data (Figures 3b-3d) to draw the boundaries between them in the new geological sketch map (Figure 2a). Indeed, the Somali Basalts are more silica-rich than the others $\left(\mathrm{SiO}_{2}: 48-52 \mathrm{wt}\right.$. $\%$ ), while Hayyabley Basalts are consistently depleted in alkalies $\left(\mathrm{Na}_{2} \mathrm{O}+\mathrm{K}_{2} \mathrm{O} \sim 2\right.$ wt.\%), and the Goumarre Basalts are, at equivalent $\mathrm{SiO}_{2}$ contents, richer in alkalies than the Gulf Basalts. Among the latter, the compositions of samples collected on both sides of the Tadjoura Gulf systematically overlap, as already noted by Richard [1979], Bizouard and Richard [1980], and Gasse et al. [1983].

[10] The studied transitional basalts contain 3 to 15 modal $\%$ phenocrysts of calcic plagioclase and magnesian olivine in a $\sim 2: 1$ ratio. These phenocrysts are set in microlitic to subdoleritic groundmass, with microcrysts of plagioclase, olivine, augite, titanomagnetite and hemoilmenite. Their crystallization order involves successively (1) magnesiochromite, usually found as inclusions within olivine phenocrysts; (2) olivine; (3) calcic plagioclase; (4) augite; and finally (5) iron-titanium oxides. It is typical of transitional and tholeiitic series, as well as the strong $\mathrm{Fe}$ enrichment documented in olivines and augites [Richard, 1979; Bizouard and Richard, 1980].

\subsubsection{Major and Trace Element Features}

[11] Selected plots of major and transition elements against total iron as $\mathrm{FeO}$ versus $\mathrm{MgO}$ ratios $(\mathrm{FeO} * / \mathrm{MgO})$ are shown in Figure 3b. Once again, the Hayyabley Basalts [Daoud et al., 2010] differ from all the other groups by their more primitive character (lower $\mathrm{FeO}^{*} / \mathrm{MgO}$ ratios, higher $\mathrm{Ni}$ concentrations), and their much lower $\mathrm{TiO}_{2}$ and $\mathrm{P}_{2} \mathrm{O}_{5}$ contents. Gulf Basalts tend to display lower $\mathrm{FeO} / \mathrm{MgO}$ ratios (1.5 to 2.5) than the Goumarre and Somali Basalts (2 to 3), as well as lower $\mathrm{SiO}_{2}\left(45-48\right.$ wt. \%), $\mathrm{TiO}_{2}, \mathrm{P}_{2} \mathrm{O}_{5}$ and $\mathrm{K}_{2} \mathrm{O}$ contents. Regarding the transition element $\mathrm{Ni}$ and others not shown $(\mathrm{Co}, \mathrm{Cr})$, they are intermediate between the relatively primitive Hayyabley Basalts and the evolved Goumarre and Somali Basalts.

[12] The envelopes of the incompatible multielement patterns of the studied basalts, normalized to the Primitive Mantle [Sun and McDonough, 1989] are shown in Figure 3c. While Hayyabley Basalts have flat to slightly depleted patterns, the Gulf, Goumarre and Somali Basalts display moderately enriched patterns, typical of Afar transitional basalts [Barrat et al., 1990, 1993; Vidal et al., 1991; Deniel et al., 1994; Rogers, 2006; Furman et al., 2006]. They plot close to the enriched component of the "Red Sea mixing line" (Figure 3c) which connects the depleted (MORB mantle) and enriched (plume-type) components of the sources of the Red Sea basalts [Barrat et al., 1990]. However, several significant differences between the patterns of Gulf, Goumarre and Somali Basalts can be noticed on these plots, and they have been used to refine the new geological map (Figure 2a). For instance, the Gulf Basalts are generally less enriched in incompatible elements (especially in the most incompatible ones, from $\mathrm{Rb}$ to $\mathrm{Ce}$ ) than the Goumarre and Somali Basalts which show strong positive Th spikes. Furthermore, Somali Basalts display a larger range of heavy rare earth element (REE; e.g., Dy and $\mathrm{Yb}$ ) contents than the other types, including higher concentrations close to ten times the Primitive Mantle. Consequently, the RRE patterns (not shown) of the Goumarre Basalts are more fractionated than those of the Somali Basalts, and the two types can easily be distinguished by their different $\mathrm{La} / \mathrm{Yb}$ ratios $(8-10$ and 6-8, respectively).

[13] Other efficient ways to distinguish the Gulf Basalts from the Goumarre and Somali Basalts are provided by the rectangular diagrams of Figure 3d, which involve incompatible element ratios showing little or moderate overlap between these three groups. Basically, all ratios using an element plotting to the left or the middle of the multielement plot (e.g., Th, Ba, Nb, La, Zr or others not shown like Rb, K, $\mathrm{Ce}, \mathrm{Sr}, \mathrm{P})$ versus an element plotting to the right $(\mathrm{Y}, \mathrm{Yb})$ may be used to distinguish the moderately enriched Gulf Basalts from the more enriched Goumarre and Somali Basalts. These geochemical plots, together with geomorphological, structural and age data, led us to shift the map limit between the Gulf and Somali Basalts in the Djibouti Plain $10 \mathrm{~km}$ further north than drawn on previous maps [Gasse et al., 1983, 1986]. In addition, the abrupt chemical change observed at a depth of $220 \mathrm{~m}$ in basalts drilled in the PK20 borehole (Figure 2a) is consistent with the transition from the upper Gulf Basalts to the underlying Somali Basalts. However, the top of the Somali pile in this borehole has been abnormally enriched in Y and heavy REE (e.g., $\mathrm{Yb}$ ), and the corresponding point has thus not been shown in Figure $3 \mathrm{~d}$ plots. Such abnormal enrichments are the consequence of the crystallization of low-temperature REEbearing phosphate (rhabdophane) during pedogenetic alteration processes [Cotten et al., 1995], prior to the emplacement of the Gulf basaltic pile.

[14] Some of the differences observed between the Gulf Basalts, on one hand, and the Goumarre and Somali Basalts, on the other hand, may be attributed to olivine fractionation. Indeed, the latter basalts display higher $\mathrm{FeO}^{*} / \mathrm{MgO}$ ratios,

Figure 2. Revised geological sketch map of the onshore parts of the Tadjoura rift. (a) Revised map showing the distribution of the various basalt types and the location of dated basaltic rocks. Ages in megayears (numbers inside the squares) from published [Richard, 1979; Gasse et al., 1983; Zumbo et al., 1995] and new data (this study, see Table 2). Tectonic features are not shown on this simplified map. Abbreviations on the map are: A, Arta; CW, Chabelley wadi; DD, Dey Dey wadi; HV, Hayyabley volcano; G, Goumarre; Gb, Goubbetto; and PK20, "Point kilométrique" 20. (b) Longitude versus age plot for the southern and northern coastal strips of Gulf Basalts. A linear age progression is not clearly observed. 

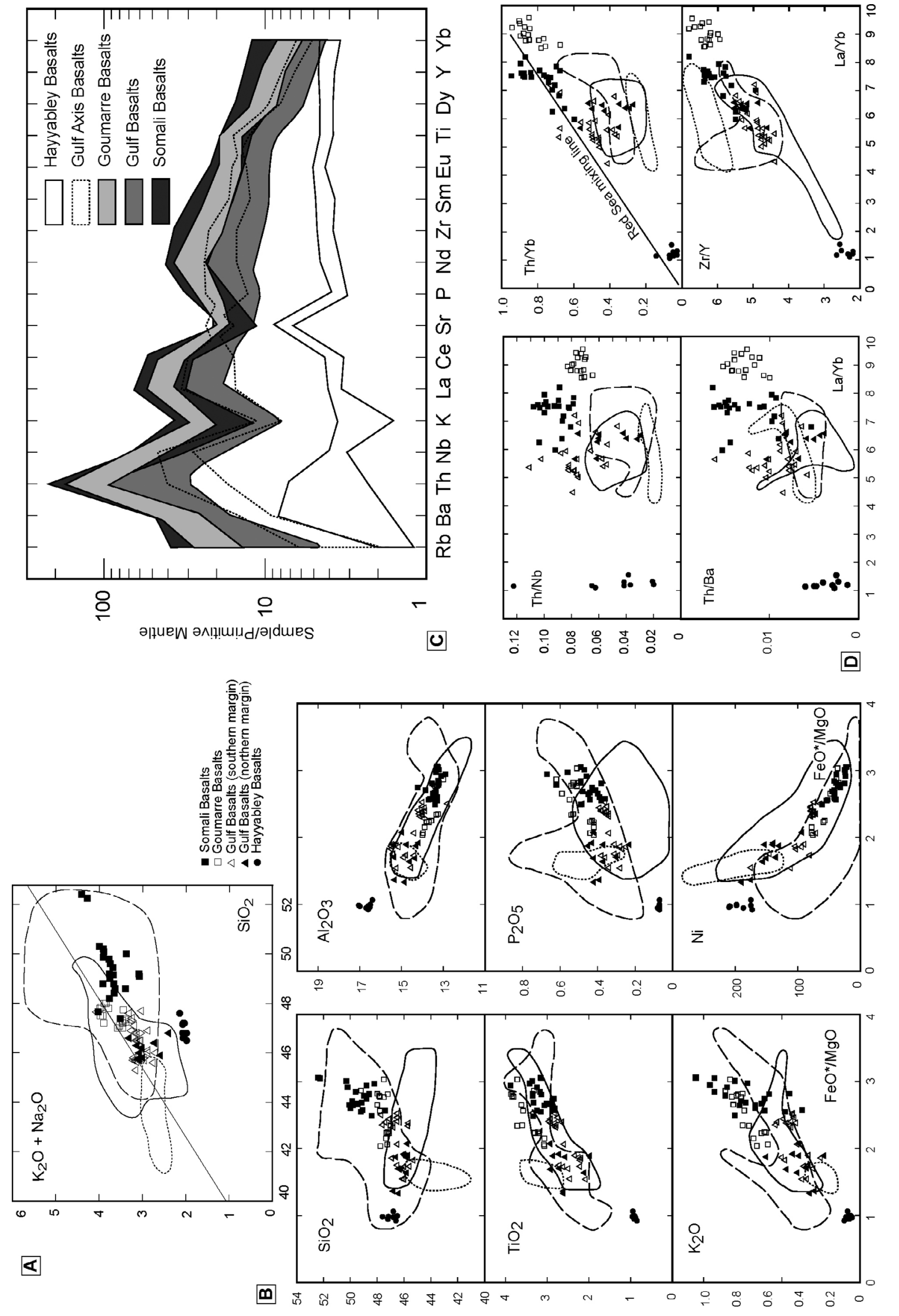

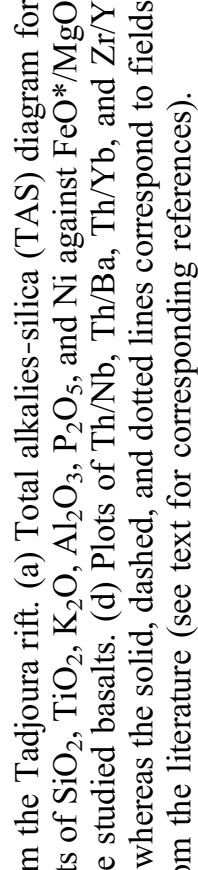

ฐี

记 0 出

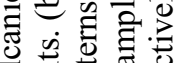

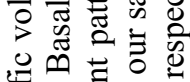

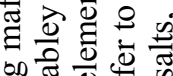

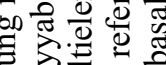

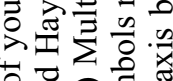

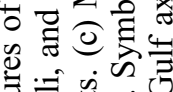

预泀泀

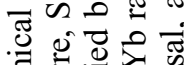

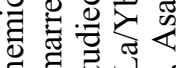

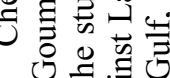

ம4

光司舟。

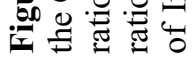


lower $\mathrm{Ni}$ and other compatible transition element contents, and higher $\mathrm{SiO}_{2}, \mathrm{TiO}_{2}, \mathrm{P}_{2} \mathrm{O}_{5}$ and $\mathrm{K}_{2} \mathrm{O}$ contents than the Gulf Basalts (Figure $3 \mathrm{~b}$ ). Olivine fractionation might also account for their higher incompatible element contents compared to the Gulf Basalts (Figure 3c). However, as this process does not fractionate appreciably ratios between highly incompatible elements (e.g., $\mathrm{Th} / \mathrm{Nb}$ and $\mathrm{Th} / \mathrm{Ba}$, Figure $3 \mathrm{~d}$ ), nor strongly modifies the shapes of REE patterns (and consequently the $\mathrm{La} / \mathrm{Yb}$ ratios [Allègre et al., 1977]), it cannot account for the differences shown in Figure $3 \mathrm{~d}$ plots. These differences might result from variations affecting partial melting degrees, mantle source heterogeneity, crustal contamination, or more likely a combination of these processes [Joron et al., 1980a, 1980b; Barrat et al., 1990, 1993; Vidal et al., 1991; Deniel et al., 1994]. In addition, the different $\mathrm{La} / \mathrm{Yb}$ ratios of the Goumarre and Somali Basalts, which display nearly equivalent enrichments in most incompatible elements, might indicate that the former derive from a deeper (i.e., garnet-bearing) mantle source than the latter, as garnet incorporates selectively heavy REE.

\subsection{Spatial Distribution and Volcano Stratigraphy of Tadjoura Rift Volcanics}

[15] The geochemical criteria discussed above, together with field mapping, allows us to propose a revised 2-D map arrangement of the Gulf Basalts, and consequently of the TR (Figures 2a and 4b). When superimposed on the morphological map of Figure 4a, the map extent of the TR corresponds to an approximately $60 \times 40 \mathrm{~km} \mathrm{EW}$ trending topographically subdued domain. The onshore part of the TR forms the Northern and Southern Coastal Fault Belts (NCFB and SCFB) in the Tadjoura-Obock and Djibouti Plain areas, respectively. The presence of Gulf Basalts in the floor of the Tadjoura Gulf is argued by dredged samples [Barrat et al., 1990, 1993], and to a lesser extent by the seismic records discussed below.

\subsubsection{Gulf Basalts in the Northern Onshore Margin}

[16] In the Tadjoura-Obock area, the Gulf Basalts occur in a $15 \times 8 \mathrm{~km}$ faulted coastal plateau, less than $300 \mathrm{~m}$ high (NCFB, Figure 4b). The main cartographic unit of the Gulf Basalts (the Roueli unit of Gasse et al. [1983, 1985]) extends to the north as a $10 \times 5 \mathrm{~km}$ faulted belt oriented $\mathrm{N} 100^{\circ} \mathrm{E}$, which swings to the northeast into a narrower $\mathrm{N} 50^{\circ} \mathrm{E}$ strip. The Gulf Basalts lie further south as discrete inliers beneath locally faulted Quaternary alluvial fans, possibly as young as Holocene [Manighetti et al., 1997]. Their rapid disappearance west of longitude $42^{\circ} 50^{\prime} \mathrm{E}$ might result from a nearly NS trending paleo-high, in the northern prolongation of the Arta zone (see section 4.3) (Figure 4a).

[17] The total thickness of the Gulf Basalts volcanic pile is estimated to $350 \mathrm{~m}$ [Gasse et al., 1985]. Its exposed part is mostly made up of superimposed columnar-jointed subaerial lava flows, the individual thickness of which reaches up to $10 \mathrm{~m}$. A few submarine lava flows have been described at the mouth of the Sadaï-Tagarré wadi [Gasse et al., 1983]. The presence of vertical mafic dykes, associated sills and plug-type feeder magmatic structures intruding tilted lava successions NE of Tadjoura confirms the fissural origin of the entire Gulf Basalts series, but it also rules out its exclusive origin from offshore vents along the TR axis [Richard, 1979]. The $\mathrm{N} 110^{\circ} \mathrm{E}$ trend of the onshore feeder dykes further indicates, in first approximation, a $\mathrm{N} 20^{\circ} \mathrm{E}$ direction of opening, slightly oblique with respect to the inferred $\mathrm{N} 40^{\circ} \mathrm{E}$ regional tectonic extension [Gaulier and Huchon, 1991].

\subsubsection{Southern Flank of the TR in the Djibouti Plain}

[18] According to the geochemical criteria presented above, the map distribution of Gulf Basalts in the Djibouti Plain (Figure 2a) is more restricted than previously assessed by Gasse et al. [1983, 1985]. They are confined to a $10 \times 20 \mathrm{~km}$ coastal faulted plateau which uprises southward, via the EW trending Ambouli topographic flexure (Figure 4e), to a northerly tilted surface in the 7.2-3.6 Myr Somali Basalts. To the east, the Gulf Basalts are overlain by lavas of the $\sim 1 \mathrm{Myr}$ old Hayyabbley shield volcano [Gasse et al., 1983; Daoud et al., 2010], the main axis of which follows a major $\mathrm{N} 140^{\circ} \mathrm{E}$ fault scarp bounding the eastern coastal plain to the southeast. The western limit of the Gulf Basalts abuts against the NS-oriented eastern edge of the Arta reliefs, although they locally fill up the Wea paleo-valley (Figure 2a).

[19] The Gulf Basalts pile consists of a succession of subaerial fluid lava flows of fissural origin. Individual flows are generally less than $10 \mathrm{~m}$ thick, and their surfaces show typical pahoehoe features; their central part often displays columnar jointing patterns. Field emplacement criteria (e.g., deformation of pahoehoe "ropy" surfaces and flow patterns at their base) indicate that they mostly flowed southward over the Djibouti Plain. Their original vents have not been recognized onshore, and therefore are presumably located in the presently submerged part of the TR. The Gulf Basalt pile reaches a maximum thickness of $220 \mathrm{~m}$ in boreholes drilled in the PK20 area to the west (Figures 2a and 4e), where they overlie the top of the Somali Basalt pile. The uppermost sequence of Gulf Basalts is exposed in the AmbouliChabelley area to the south (Figure 4e). It includes a succession of thin ( $<1 \mathrm{~m}$ thick) subaerial lava flows, interdigitated with conglomeratic alluvial horizons (basaltic boulder-rich facies). The latter probably derived from uplifted reliefs in the Arta and Somali surrounding domains. The young and flat lying Gulf Basalts flows onlap previously tilted Somali Basalts along the Ambouli flexural zone (Figure 4e).

[20] Available K-Ar and Ar-Ar ages of Gulf Basalts from the Djibouti Plain range from 2.8 to 1.5 Myr (Figure 2a) [Richard, 1979; Gasse et al., 1983; Zumbo et al., 1995]. This range can be extended to $1.19 \mathrm{Myr}$ and 1.09 Myr (Table 2) taking into account our new results on Gulf Basalts flows from the Wea paleo-valley (Figure 2a). In the Warabor wadi cross section, the Gulf Basalts pile is overlain by the Hayyabley volcano lava flows which yielded ages of $1.06 \pm 0.09 \mathrm{Myr}$ and $0.93 \pm 0.06 \mathrm{Myr}$ [Daoud et al., 2010]. The 3.3 Myr old basaltic rocks located to the southeast of the Ambouli wadi were previously assigned by Richard [1979] to the Gulf Basalts. Their geochemical features allow us to consider them as part of the Somali series. Therefore, the revised longitude versus age plots drawn for the southern and northern Gulf Basalts (Figure 2b) can no longer be used to support the idea of an age decrease toward 
the west [Richard, 1979; Manighetti et al., 2001; Audin et al., 2004].

[21] The approximately 7.2-3.0 Myr old Somali Basalts [Chessex et al., 1975], which cover most of the Djibouti
Plain south of the Ambouli regional-scale flexure, form a monotonous and weakly incised plateau (Figures $4 \mathrm{a}, 4 \mathrm{~b}$, and $4 \mathrm{e})$. They likely represent a trap-like pile, similar to the nearly contemporaneous (8.6-3.8 Myr) Dalha basaltic series

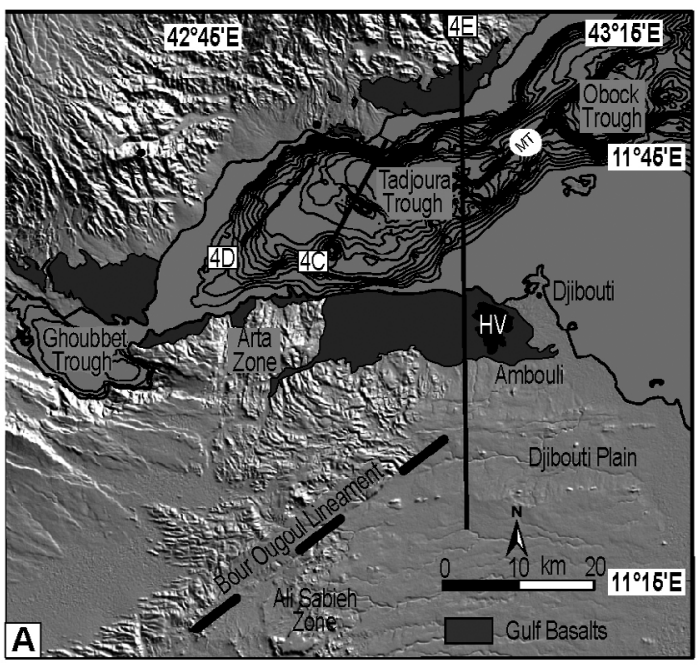

${ }^{0.0}{ }^{\mathrm{NE}}$

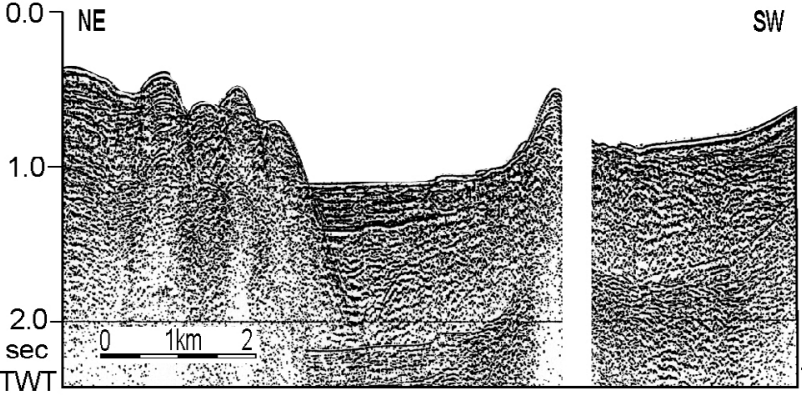

SW ${ }^{0.0} 7 \mathrm{NE}$
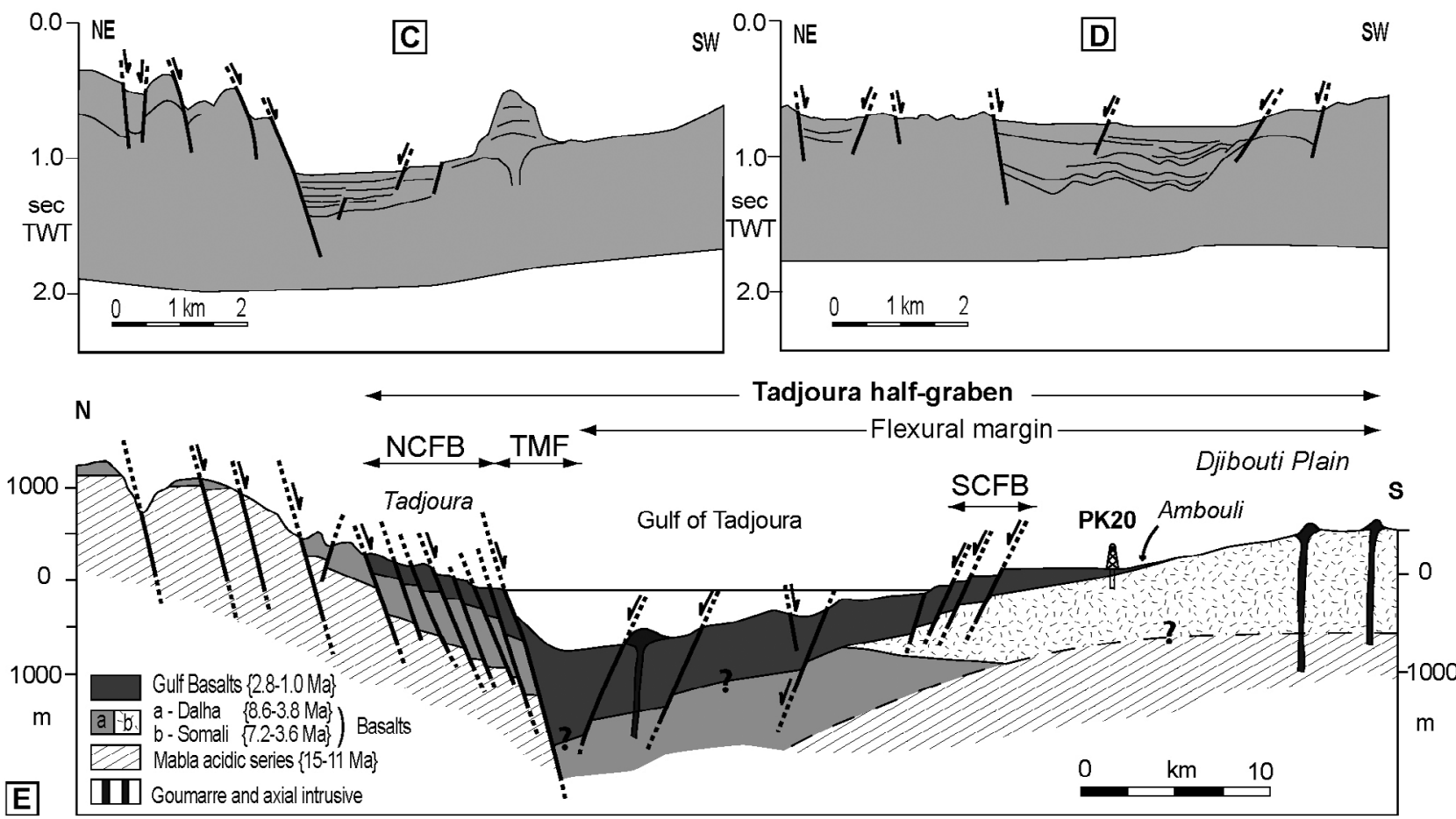

Figure 4 
located northwest of the Djibouti Plain [Marinelli and Varet, 1973; Barberi et al., 1975]. In the Holhol area (Figure 2a), the Somali Basalts rest unconformably over tilted, and partially eroded, rhyolitic sequences of the 15-11 Myr old Mabla series [Black et al., 1975; Zumbo et al., 1995]. Because of restricted exposures and difficult access conditions, their total thickness and their internal organization are poorly known. The 30-40 m high sections exposed along the Dey Dey wadi (Figure 2a) show up to ten superimposed subaerial basaltic flows, either columnar-jointed or showing lava tubes. They range in thickness from 1 to $10 \mathrm{~m}$, and are often separated by autoclastic breccia levels and/or by strombolian lapilli horizons up to $1 \mathrm{~m}$ thick. A $30 \mathrm{~m}$ high cross section near Goumarre volcano (Figure 2a) exposes seven superimposed subaerial basaltic flows, each of them 2 to $8 \mathrm{~m}$ thick, emplaced toward the north (i.e., in an opposite direction to that of the Gulf Basalts), according to local field criterions. Mafic dykes crosscutting Somali lavas in the Goubetto area to the west (Figure 2a) consist of $\sim 1 \mathrm{~m}$ thick vertical intrusions, oriented $\mathrm{N} 80-90^{\circ} \mathrm{E}$, i.e., slightly oblique to the $\mathrm{N} 110^{\circ} \mathrm{E}$ Gulf Basalts feeder dykes.

[22] With respect to the intricate swarm of young volcanoes which punctuate the Djibouti Plain (Figure 2a), special attention has been paid to three $\mathrm{N} 80^{\circ} \mathrm{E}$ parallel arrays of basaltic vents crosscutting the Somali lavas, and referred here as to the Goumarre Basalts (from their type locality, i.e., the Goumarre strombolian lapilli/ash cone, dated at $1.75 \mathrm{Myr}$ by Gasse et al. [1983]). These volcanic corridors, each of them a few $\mathrm{km}$ wide, are sharply cut to the east by the $\mathrm{N} 140^{\circ} \mathrm{E}$ coastal scarp. To the west, their tips remain within the Somali Basalts and do not reach the older substratum series of the Ali Sabieh range. In addition to numerous small strombolian or maar-type volcanoes, with maximum height of approximately $100 \mathrm{~m}$, the Goumarre Basalt series includes various types of intrusions (dykes, sills, plugs), often spatially connected with these volcanoes. The genetic relationships between Goumarre-type lavas and their inferred magmatic feeders can be observed on aerial photographs of the Dey Dey central corridor in the Goumbourta Atar strombolian cone area (Figure 2a). There, lava flows seem to either radiate from small-scale vents, or diverge on both sides of $\mathrm{N} 80^{\circ} \mathrm{E}$ trending fault/fissure structures which correlate in the field with narrow (1-2 m thick) dykes and thicker $(15 \mathrm{~m})$ sills crosscutting the Somali Basalts. Most of the Goumarre Basalts are therefore likely to have been emitted from transverse fault/dyke corridors, nearly parallel to the present-day Gulf axis. Published radiometric ages from the Goumarre $(2.46,1.84,1.80,1.75 \mathrm{Myr})$ and Nagad (1.69 Myr) cones [Richard, 1979; Gasse et al., 1983] are younger than those obtained from the Somali Basalts (3.40, 3.30, 2.93 Myr) [Richard, 1979; Zumbo et al., 1995] (Figure 2a). It is therefore suggested that the Goumarre Basalts were emplaced during a relatively short time interval, concomitantly with the Gulf Basalts, but in a more southern, i.e., external, position with respect to the TR framework.

\section{Half-Graben Structure of the Tadjoura Rift}

[23] The overall 3-D architecture of the TR is discussed below, both in terms of map fault arrangement, and crosssectional structure, from exposed geology and offshore bathymetric and seismic data set (Figure 4). A quantitative analysis of onshore fault populations in the NCFB and SCFB was also performed from ASTER imagery measurements. Emphasis is then put on two specific structural features in the western extremity of the TR, i.e., the Arta sumeridian zone and a network of NW-SE faults, which are both regarded as key elements for a better understanding of the mechanism of strain transfer in the Tadjoura-Ghoubbet transition rift zone.

\subsection{Two-Dimensional Map Structure}

[24] The TR is an approximately $60 \times 40 \mathrm{~km} \mathrm{EW}$ trending topographically subdued domain, partly exposed onshore in the NCFB and SCFB, on both sides of the Tadjoura Gulf (Figures $4 \mathrm{a}$ and $4 \mathrm{~b}$ ). Its inner offshore part is dominated to the north by the $\mathrm{N} 120^{\circ} \mathrm{E}$-oriented Tadjoura rhomb-shaped trough which is sinistrally offset from the Obock depression by approximately $30 \mathrm{~km}$ along the right-lateral Maskali transform fault system [Arthaud and Choukroune, 1976]. The TR is surrounded by highlands involving older riftrelated volcanics of the Mabla (18-11 Myr, in Gasse et al. [1985]), Dalha (8.6-3.8 Myr), Somali (7.2-3.6 Myr), and Ribta (3.6 Myr) series. It is dissected by an inhomogeneously distributed fault pattern, comprising Gulf-parallel, NW-SE and NE-SW structures. The map-scale sigmoid trace of the entire fault pattern typically evokes an oblique

Figure 4. Overall structure of the Tadjoura rift. (a) Topography of the TR drawn from a bathymetric contour map (from Audin [1999], modified) and a SRTM digital elevation model. Dashed lines represent the Maskali transform (MT) and Bour Ougoul transverse fault systems. Note the strong NS-oriented structural grain in the Arta zone. The traces of the structural cross section in Figure $4 \mathrm{e}$ and the two interpreted seismic profiles in Figures $4 \mathrm{c}$ and $4 \mathrm{~d}$ are shown. HV represents Hayyabley volcano. (b) Structural map of the TR obtained (1) by merging onshore geology with offshore bathymetric data set and (2) by using the Gulf Basalts as a rift marker (only drawn onland). Abbreviations on the map are: ATZ, Arta transverse zone; HV, Hayyabley volcano; NCFB, Northern Coastal Fault Belt; and SCFB, Southern Coastal Fault Belt. (c and d) Raw (top) and interpreted (bottom) TADJOURADEN offshore seismic profiles (time sections) perpendicular to the NW-SE-oriented fault-controlled Tadjoura inner trough (see traces in Figure 4a). (e) Interpretative structural cross section showing the Tadjoura rift as a south facing half-graben, partly filled up by Gulf Basalts. The elements of the deep structure of the Tadjoura rift are conjectural. The geometrical relationships between the underlying Somali and Dalha basalts are extrapolated from patterns observed onshore along the Bour Ougoul lineament on the NW flank of the Ali Sabieh antiform (see Figure $4 \mathrm{a}$ for location). 
rift setting. Two high-density fault zones occur on the eastern parts of the conjugate margins, in the Tadjoura trough and the NCFB to the north, and in the SCFB to the south. In the intermediate and less deformed zone, the preferred $\mathrm{N} 60^{\circ} \mathrm{E}$ alignment of shield-like volcanoes might be controlled at depth by Maskali-type transverse structures (Figure 4b). To the west, the TR narrows markedly, north of the Arta transverse zone, where its floor shallows abruptly, up to 100-200 m below sea level, through a submeridian scarp disrupted by an array of isolated NW-SE faults. The TR fault system does not extend beyond the Gulf Basalts, e.g., into the substratum series which instead show evidence for earlier deformation (see sections 4.2-4.4).

\subsection{Half-Graben Cross-Sectional Structure}

[25] The composite structural cross section in Figure 4e, drawn at high angle with respect to the dominant N110 $120^{\circ} \mathrm{E}$ fault strike in the TR, is calibrated by TADJOURADEN bathymetric and seismic reflection data which have been merged with onshore geology. It shows a 35-40 km wide half-graben structure, facing the SSW. Its inner and deeper part is occupied by the Tadjoura trough, which is bounded to the north by a prominent fault system, including the Tadjoura master fault, and its highly faulted footwall block, partly exposed in the NCFB. To the south, an approximately $20 \mathrm{~km}$ long typical flexural margin shallows gradually southward, up to the Djibouti Plain, where Gulf Basalts are locally dissected by a high-density antithetic fault system in the SCFB. The flexure is locally punctuated by shield volcanoes.

[26] The deep structure of the Tadjoura inner trough is constrained down to about $2 \mathrm{~s}$ (two-way travel time), or depth of 4-5 km, by selected single-channel seismic reflection profiles striking NE-SW, orthogonal to the prominent bathymetric scarps (Figures $4 \mathrm{c}$ and $4 \mathrm{~d}$ ). To the north, the steep bathymetric scarp, $>500 \mathrm{~m}$ high and facing the SSW on the seismic line of Figure 4c, is interpreted as the upper part of the master fault. High-amplitude reflectors lying, with an apparent gentle dip, in its immediate hanging wall are reliably correlated with Gulf Basalts dredged from the Tadjoura gulf [Barrat et al., 1990, 1993]. Similar seismic facies present, with a reduced thickness, in the elevated footwall block correlate laterally with onshore Gulf Basalts in the NCFB (Figure 4b), hence confirming our seismostratigraphic interpretation. The volcanic infill sequence thickens markedly toward the boundary fault, just like synfaulting deposits, up to a maximum thickness of 7-800 m. This value is obtained by converting the $0.3 \mathrm{~s}$ (two-way travel time) measurement, assuming an average seismic velocity for basalts of 4.5-5.0 $\mathrm{km} \mathrm{s}^{-1}$.

\subsection{Footwall Block Structures in the NCFB}

[27] The deep structure of the footwall block comprises a network of closely spaced and dominantly synthetic extensional faults. These structures bound narrow blocks stepping down gradually toward the trough (Figure 4c). The footwall fault system continues onshore into the NCFB, with a marked swing of the dominant fault trend into a $\mathrm{N} 100^{\circ} \mathrm{E}$ direction (Figures $4 \mathrm{~b}$ and $5 \mathrm{a}$ ) and additional
$\mathrm{N} 20^{\circ} \mathrm{E}$ and $\mathrm{N} 50^{\circ} \mathrm{E}$ (Maskali trend) faults. Two submeridian $\mathrm{E}$ facing extensional faults $\left(\mathrm{F}_{21}\right.$ and $\mathrm{F}_{22}$ in Figure 5a), with vertical displacements of $60 \mathrm{~m}$ and $50 \mathrm{~m}$, respectively, were also identified. Their crosscutting relationships with the $\mathrm{N} 100^{\circ} \mathrm{E}$ fault pattern (either interrupted or not, and with or without apparent offset) suggest their synchronous development.

[28] Fault patterns are well exposed in the Roueli northern unit, a feature which permits an accurate geometrical and statistical analysis of the corresponding fault population. There, Gulf-parallel faults are partially blanketed to the west by 1.4-0.8 Myr old Quaternary alluvium [Gasse, 1991]. Similarly trending faults occur further south through both inliers of Gulf Basalts and overlying Holocene alluvial deposits. Two of these faults extend westward across Mabla acidic volcanics, with minor extensional displacement [Manighetti et al., 1997].

[29] The dominant $\mathrm{N} 100^{\circ} \mathrm{E}$ fault set is composed of isolated and highly segmented structures showing curved map traces (Figure 5a). The measured tip-to-tip length of the total fault data set (99 data) ranges from 0.4 to $6.0 \mathrm{~km}$, with a peak at $1.2 \mathrm{~km}$, and $90 \%$ of length values less than $2.8 \mathrm{~km}$ (Figures $6 \mathrm{~b}$ and $6 \mathrm{c}$ ). Fault population is homogeneously distributed, but with a marked increase of fault spacing westward (Figure 6d). Individual faults are clustered into 4 to 5 major faults facing the south, and causing the downwarping of the Gulf Basalts toward the gulf axis. Very few antithetic structures, with minor associated displacement, do occur (e.g., $\mathrm{F}_{80}$ in Figure 5b). Along-strike variations of individual fault profiles are observed on the three orthogonal cross sections shown in Figure 5b. The horizontal surface of most individual footwall blocks suggests nonrotational structures. The largest throw values $(>50 \mathrm{~m})$ systematically occur along the oldest (prealluvium) faults to the north. However, estimates of throws along the youngest (postalluvium) faults to the south might be underestimated because of syn-faulting alluvial screes at the foot of some fault scarps. Vertical throw in the oldest fault network to the north increases markedly southward from $65 \mathrm{~m}\left(\mathrm{~F}_{6}\right), 100 \mathrm{~m}$ $\left(\mathrm{F}_{4}\right)$ to $>130 \mathrm{~m}\left(\mathrm{~F}_{8}\right)$. A comparison of the three topographic sections shows that the total fault-induced elevation slightly decreases westward from $310 \mathrm{~m}$ (section 1) to $280 \mathrm{~m}$ (section 2), and to $200 \mathrm{~m}$ (section 3). These along-strike variations of cumulate fault displacement are illustrated by the distribution of throw along some individual structures, such as faults labeled $\mathrm{F}_{1-7-19}$ or $\mathrm{F}_{4-16}$, the tip of which lies close to the substratum contact to the west.

[30] The cumulative bulk extension along three regularly spaced sections across the fault system (Figure 6a) has been calculated with a mean fault dip of $60^{\circ}-70^{\circ}$, similar to those reported elsewhere in the Afar depression [de Chabalier and Avouac, 1994]. The bulk extension decreases regularly from $3.4 \%$ to $1.6 \%$ westward. Special attention has been paid to the displacement-length ratio $(D / L)$, which may supply information about fault growth processes [Cowie and Scholz, 1992a, 1992b; Dawers et al., 1993; Manighetti et al., 2001], as a function of either the restricted versus unrestricted nature of the faults [Watterson, 1986; Gillespie et al., 1992], or the mechanical heterogeneity of the stressed medium [Trudgill and Cartwright, 1994; Wojtal, 1994]. D refers to 

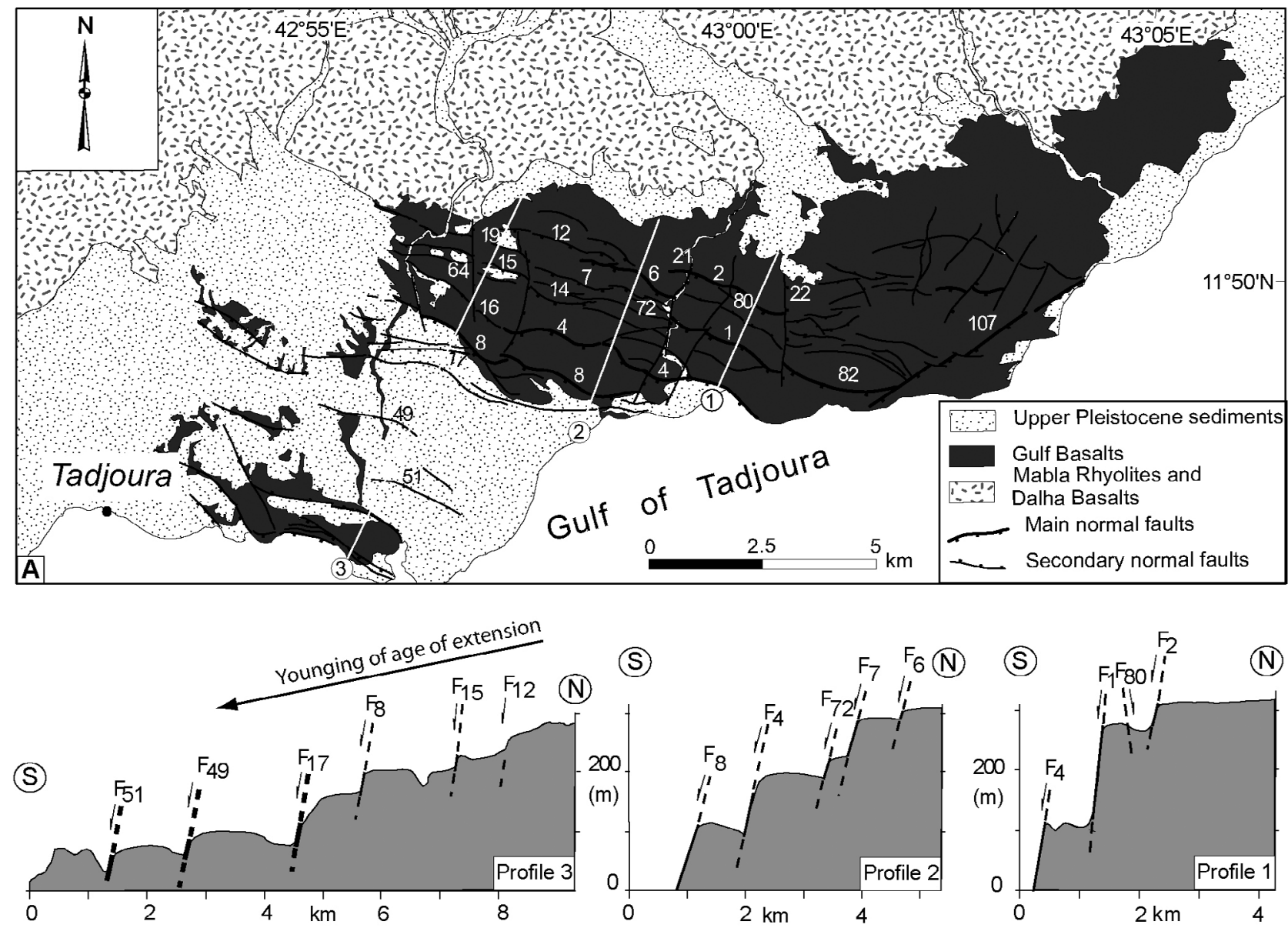

B

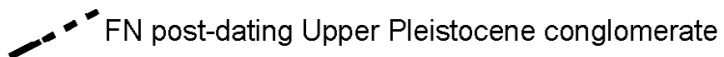

- FN pre-dating Upper Pleistocene conglomerate

Figure 5. Map distribution and morphological expression of extensional structures in the North Coastal Fault Belt. (a) Structural map showing fault traces extracted from ASTER satellite images (vertical resolution $15 \mathrm{~m}$ ). Numbers refer to major individual structures. White lines indicate the trace of cross sections in Figure 5b. (b) Three topographic cross sections illustrating changes in fault geometry both alongstrike and perpendicular to the $\mathrm{N} 100^{\circ} \mathrm{E}$ rift axis. Note the progressive increase of fault scarp size toward the south within each cross section and toward the west from profiles 1 to 3 .

maximum displacement and $L$ to fault trace length in map view. Classical fault growth models predict that displacement is maximal at or near the center of the fault and decreases toward its tips [Cowie and Scholz, 1992a, 1992b]. It is also generally accepted that the scaling relationship between $L$ and $D$ is:

$$
D=c L^{n}
$$

where $c$ is a constant and $n$ is a scaling exponent, ranging from 0.5 [Fossen and Hesthammer, 1997] to 1.5 [Walsh and Watterson, 1988; Gillespie et al., 1992; Dawers et al., 1993; Schlische et al., 1996]. When $n=1$, as commonly accepted [Cowie and Scholz, 1992a, 1992b; Dawers et al., 1993], the above equation corresponds to a linear scaling law. The value of $c$ is an expression of fault displacement per length unit. For a linear scaling law (i.e., $n=1), c$ is simply the $D / L$ ratio which characterizes the fault population. In the log-log plot of maximum fault displacement versus length, Schlische et al. [1996] have defined a best fit linear curve with $D=0.03 \mathrm{~L}$.

[31] Manighetti et al. [2001] showed that the cumulative slip distribution along fault systems in the Afar region is related to their time-space growth and propagation history, and they proposed a best fit linear curve with $D=0.04 L$. These authors indicated that the maximum $D / L$ values are characteristic of restricted faults which plot above the $D=$ $0.04 \mathrm{~L}$ line, while unrestricted faults plot below this line. In the present work, the $D / L$ ratios calculated for $\mathrm{N} 100^{\circ} \mathrm{E}$ faults (29 data) are in the range $0.0062-0.15$, and thus plot below or along the line $D=0.04 L$ (excepted one biased value due to measurement error) (Figure 7a). In agreement with the model of Manighetti et al. [2001], this feature indicates that 
Northern margin
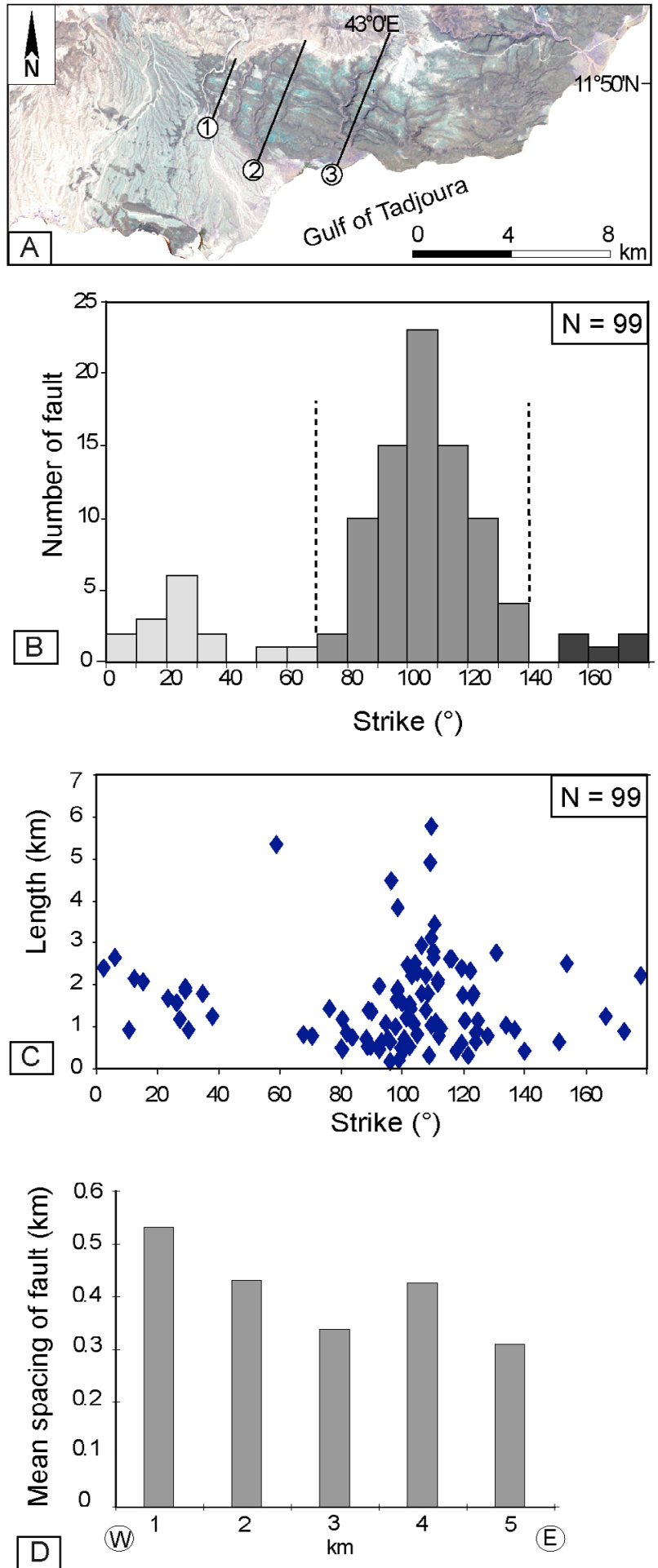
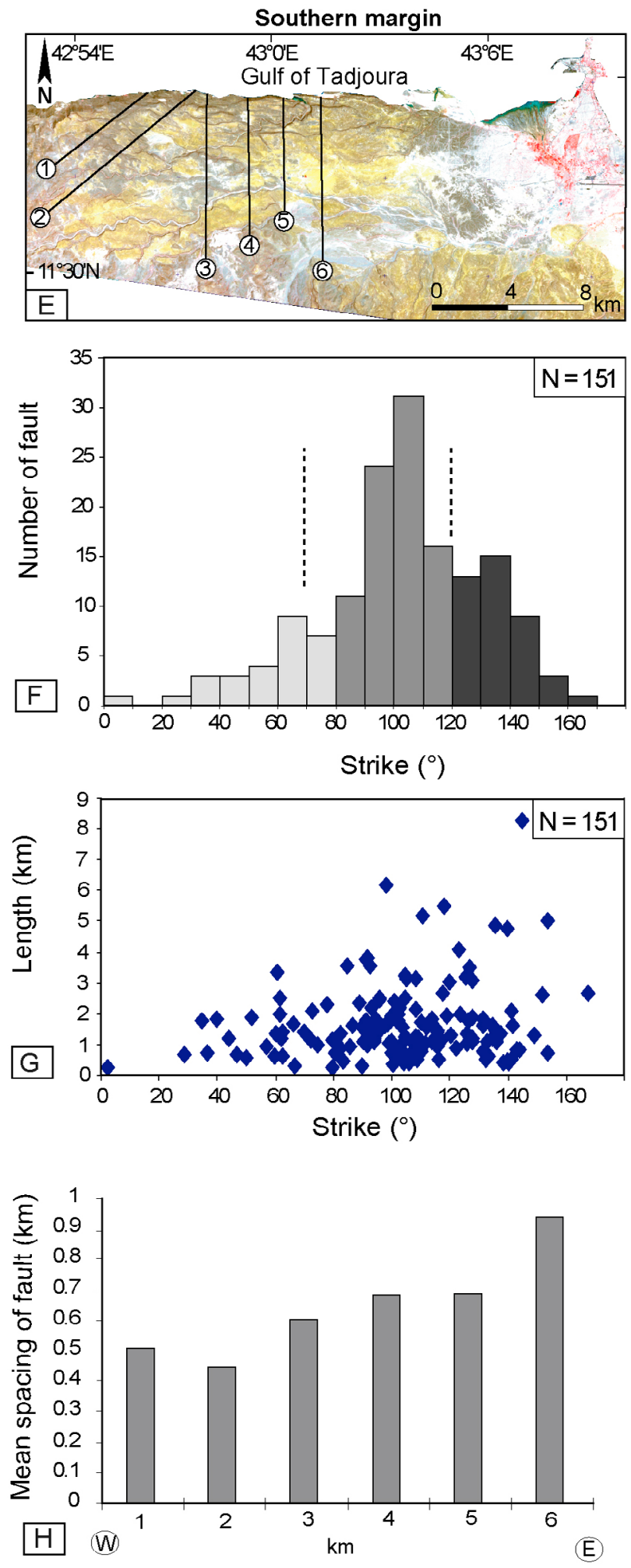

Figure 6. Geometrical and statistical characteristics of extensional fault networks in the (left) North and (right) South Coastal Fault Belts. (a and e). General 2-D fault patterns on ASTER images. The traces of cross sections used for calculating cumulate extension are shown. (b and f). Histograms illustrating the frequency versus strike of faults. (c and g). Plots of faults length versus strike. ( $d$ and $h$ ). Average spacing of faults along regularly spaced (1 km apart) profiles through the North and South Coastal Fault Belts. (Traces of the profiles are not drawn). 

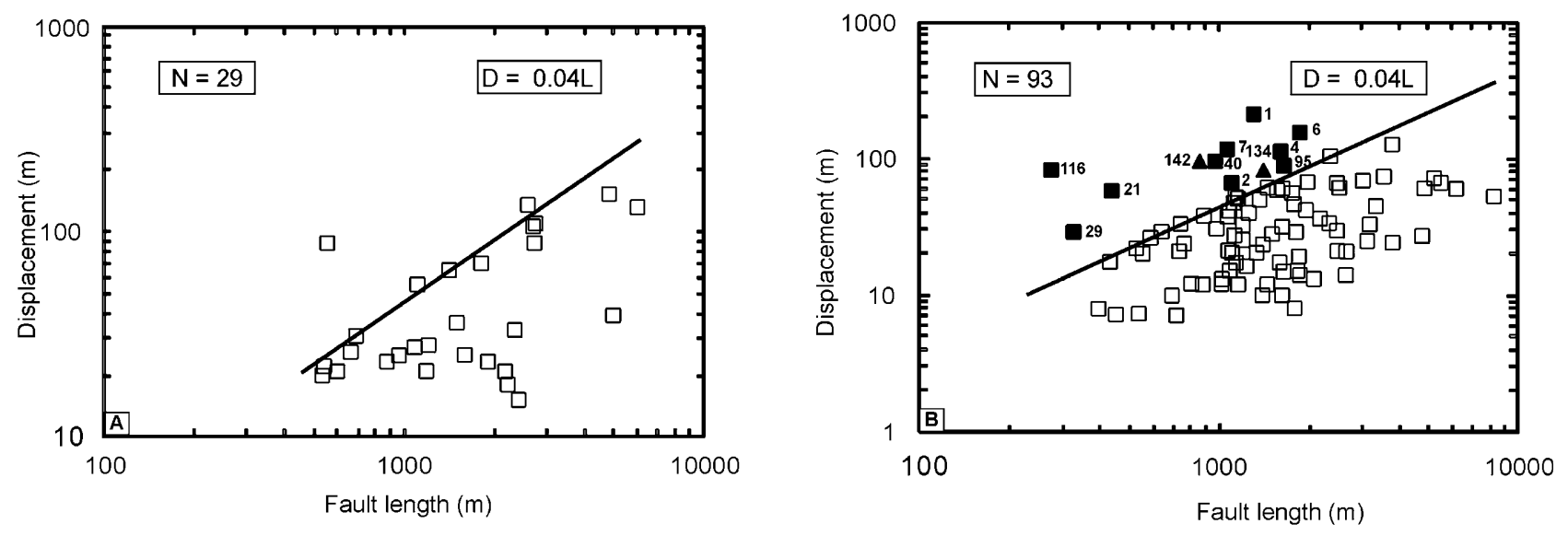

Figure 7. Log-log plot of maximum fault displacement versus fault length for structures in the (a) North and (b) South Coastal Fault Belts. The straight line corresponds to the best fit correlation $(D=$ $0.04 L$ ). Open and solid symbols denote unrestricted and restricted (overdisplaced) faults, respectively. In Figure $7 b, 10$ out of 12 overdisplaced faults are located close to the Arta zone. Corresponding fault numbers are identical to those shown in Figure 8a.

the $\mathrm{N} 100^{\circ} \mathrm{E}$ extensional fault network in the NCFB might be unrestricted.

\subsection{Faulted Marginal Flexure in the SCFB}

[32] Faulting throughout the half-graben flexural margin is mainly restricted to the $10 \mathrm{~km}$ wide belt of onshore Gulf Basalts in the SCFB (Figure 8a). However, a number of $\mathrm{N} 140^{\circ} \mathrm{E}$ transverse faults appear to continue offshore throughout a less deformed area, north and west of the Arta zone (see section 4.5).

[33] The SCFB fault network displays a much more intricate organization than that described above for the NCFB conjugate margin (Figure 8a). It includes three distinct sets of faults at $\mathrm{N} 100-110^{\circ} \mathrm{E}, \mathrm{N} 130-140^{\circ} \mathrm{E}$, and to a lesser extent $\mathrm{N} 60-70^{\circ} \mathrm{E}$ (Figure 6f). The dominant $\mathrm{N} 100^{\circ} \mathrm{E}$ antithetic fault pattern (with respect to the Tadjoura master fault) veers clockwise westward into a $\sim 5 \mathrm{~km}$ wide swarm of probably coeval $\mathrm{N} 140^{\circ} \mathrm{E}$ faults. The map curvature of Gulfparallel structures is accompanied by an increasing density of faults (Figures $6 \mathrm{~h}$ and $8 \mathrm{a}$ ), which, accordingly, decrease in length. The majority of fault lengths $(80 \%)$ are in the range $0.8-2.6 \mathrm{~km}$, with a peak at $1.2 \mathrm{~km}$ (Figure $6 \mathrm{~g}$ ), i.e., quite similar to the values obtained for the northern structures. Most Gulf-parallel faults are sigmoid or curved in map view, and the en échelon arrangement of some of them (Figure 8a) might indicate a significant component of sinistral shearing. However, their dominantly extensional nature is evidenced on the cross sections of Figure $8 \mathrm{~b}$ by typical north dipping morphological scarps which bound a network of weakly rotated fault blocks. The entire fault system is organized into 2 to 3 first-order fault blocks with an increasing structural complexity westward, evidenced on profiles 1 to 4 by (1) a larger number of north dipping faults of reduced length, and (2) additional minor south dipping faults, which together delineate second-order horst-graben patterns (Figure 8b). On each structural section, maximum fault displacement is recorded along the coastal (innermost) structures, in a way symmetrical to that observed in the NCFB. Cumulate vertical fault displacement perpendicular to fault system increases regularly westward, from $100 \mathrm{~m}$ (profile 1) to $250 \mathrm{~m}$ (profile 4), and $450 \mathrm{~m}$ (profile 5), together with the structural complexity mentioned above. The cumulative extension calculated along six cross sections (Figure 6e) provides low values, in the range $1.4 \%$ to $3.8 \%$, with a significant increase westward, such as in the NCFB. The $D / L$ ratios for the Gulf-parallel structures ( 93 data) vary from 0.0044 to 0.16 , and most of them plot below the line $D=0.04 L$, as typical unrestricted faults. Higher $D / L$ ratios $(>0.04)$ occur in the westernmost network of extensional faults which extend close to the Arta zone. These faults, labeled 1, 2, 4, 6, 7, 21, 29, 40, 95, 116 and 134 on Figure 8a, are likely to correspond to restricted and overdisplaced structures (Figure 7b).

\subsection{Southwestern Edge of the TR and the Arta Zone}

[34] Near the western termination of the TR, the width of the rifted domain decreases from 40 to less than $10 \mathrm{~km}$, together with the abrupt shallowing of the seafloor westward, from $500 \mathrm{~m}$ up to $100-200 \mathrm{~m}$ below sea level. These structural changes occur through a $2-3 \mathrm{~km}$ wide submeridian morphological scarp (Figure 9a), in the northern prolongation of the NS trending Arta zone. This offshore scarp is dissected by a series of parallel N120-140 $\mathrm{E}$ faults (Figure 8a), with very little bathymetric expression in the seismic line shown on Figure $4 \mathrm{~d}$. These faults contribute to the downthrowing of the seafloor toward the Tadjoura trough to the east. The seismic activity recorded in the western extremity of the TR since the 1970s corresponds to relatively shallow earthquakes $(<5-6 \mathrm{~km}$ deep) with moderate magnitudes $(<3.2)$ [Doubre, 2004]. These earthquakes are distributed along NW-SE-oriented seismic zones, and the corresponding fault plane solutions indicate dominantly left-lateral slip along N140 ${ }^{\circ}$ trending structures (Figure 9a) [Lépine et al., 1980; Lépine and Hirn, 1992]. 

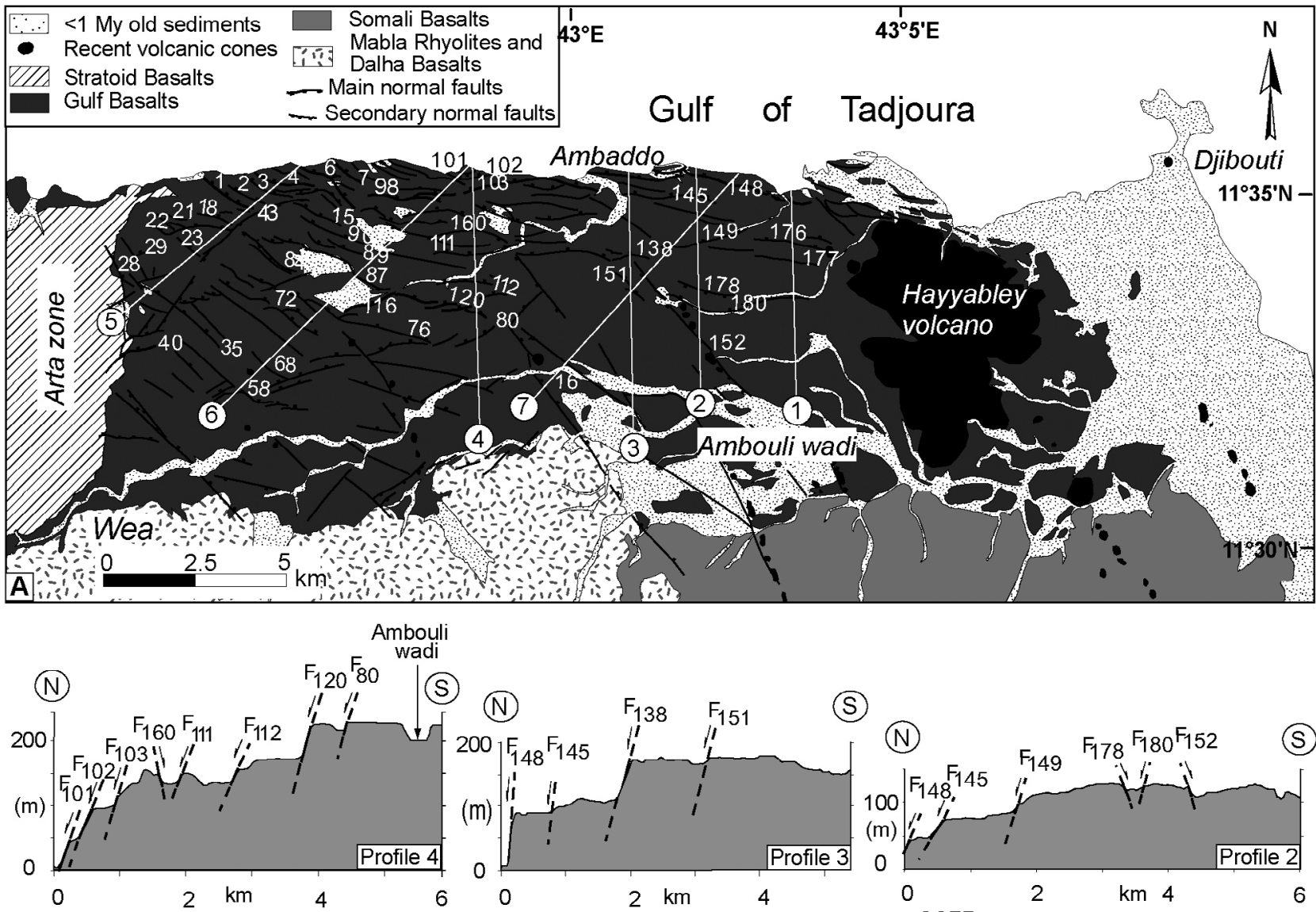

(S)

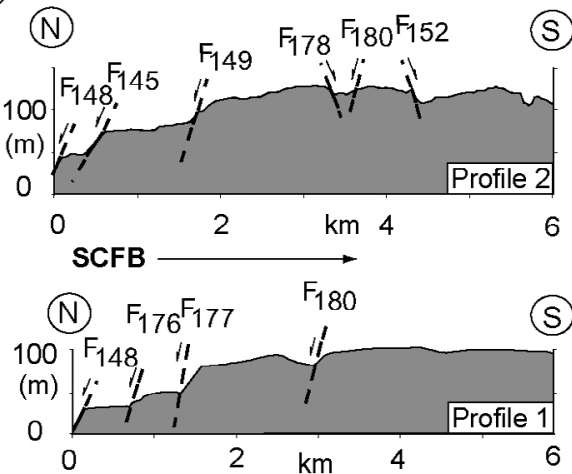

Figure 8. Map distribution and morphological expression of the extensional fault pattern in the South Coastal Fault Belt. (a) Structural map from ASTER remote sensing data interpretation. White lines are the traces of the seven topographic cross sections shown in Figures $8 \mathrm{~b}$ (profiles 1 to 4 ) and $9 \mathrm{~b}$ (profiles 5 to 7 ). (b). Morpho-structural NS trending cross sections showing increasing structural complexity toward the Arta zone to the west.

Several NW-SE transverse faults extend further to the SE, onshore, through the Gulf Basalts which cap the SCFB (Figure 9a). There, they form isolated and segmented structures, locally outlined by a dense swarm of small volcanic vents, $\sim 1$ Myr old [Gasse et al., 1983]. They show a longer and more linear map trace than the Gulf-parallel faults, with which they usually merge. Transverse faults dip consistently toward the NE, and their cumulate extensional displacement increases regularly toward the Arta zone, in association with the approximately $300 \mathrm{~m}$ elevation of the topography (Figure 9b). Extensional scarp heights measured along the major NE facing faults gradually increase westward from $20 \mathrm{~m}$ and $50 \mathrm{~m}$ (profile 7), to $70 \mathrm{~m}$ and $80 \mathrm{~m}$ (profile 6), and lastly $70 \mathrm{~m}, 30 \mathrm{~m}$ and $90 \mathrm{~m}$ (profile 5). The $D / L$ ratios calculated for transverse faults $(21$ data) are in the range $0.0056-0.022$, i.e., lower than those of the Gulf- parallel faults. The low $D / L$ ratios indicate a deficit of vertical displacement with respect to fault length, as typically documented during fault growth processes dominated by linkage where fault length increases without increasing height [Cartwright et al., 1995]. This feature is consistent with the isolated, linear and linked characteristics of the transverse faults cited above.

[35] The sketch structural map in Figure 9a shows that very few transverse and Gulf-parallel TR-related faults crosscut the $>3$ Myr old volcanic terranes forming the Arta zone. In this area, the 8.6-3.8 Myr old Dalha Basalts and the overlying Ribta felsic lavas (3.6 Myr) are involved into a broad, $10 \mathrm{~km}$ wide, upright arched structure, oriented N-S, i.e., nearly orthogonal to the E-W axis of the TR. This Arta anticline is in turn dissected by a dense network of NS-N $20^{\circ} \mathrm{E}$ fault/ fractures, parallel to the anticline axis and locally intruded by 


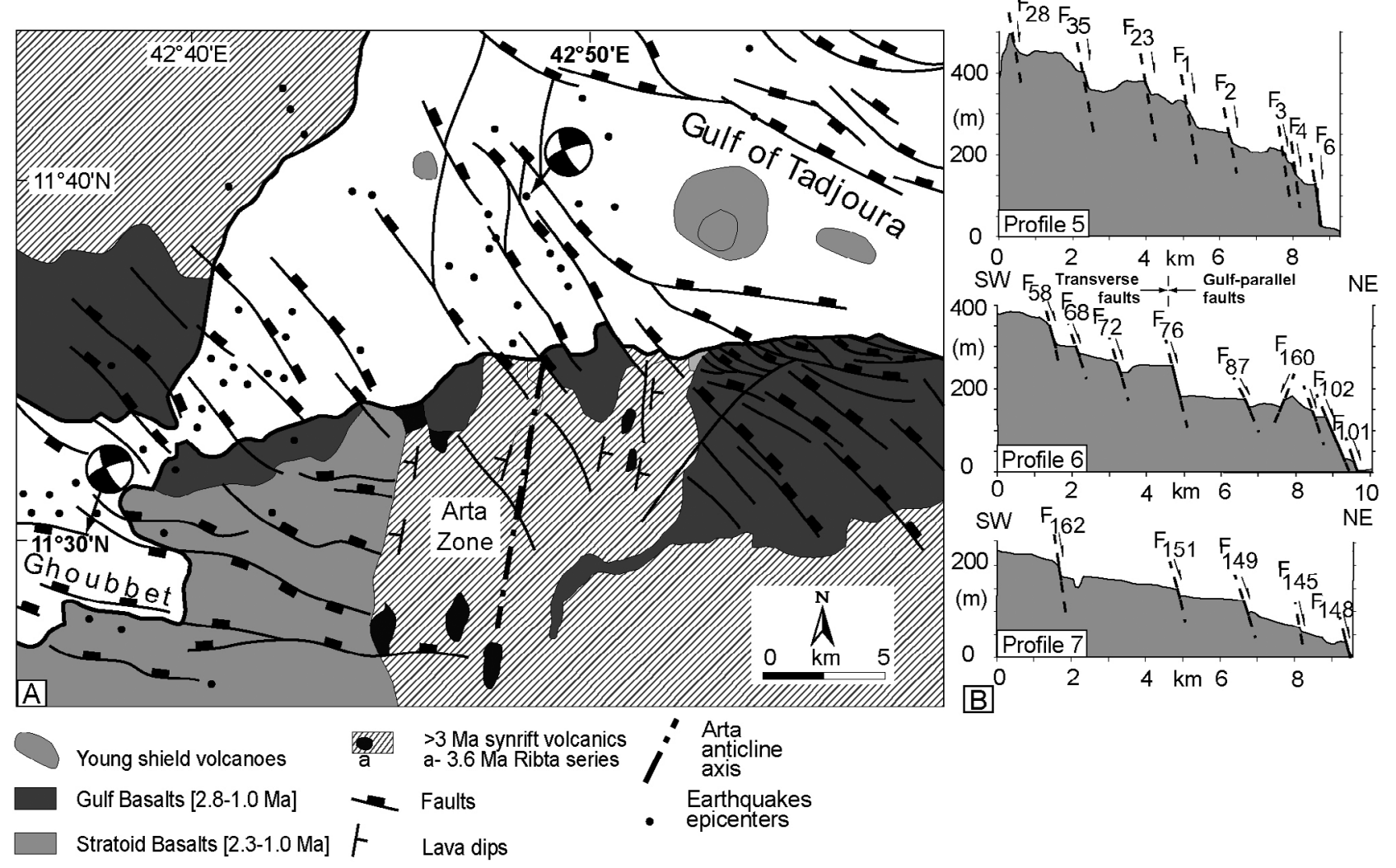

Figure 9. Onshore and offshore structural features in the transfer zone between the Tadjoura and the Ghoubbet rifts. (a) Structural sketch map showing the nearly underformed nature of the Arta transverse zone during recent $(<3 \mathrm{Myr})$ rift stages. Note that most earthquakes and faults cutting through the Stratoid and Gulf basalts avoid the Arta NS trending zone. The earthquake epicenters are from Doubre [2004], and the focal mechanisms of the 21 December 1978 and 11 August 1978 earthquakes in the Tadjoura Gulf and Ghoubbet trough, respectively, are from Lépine and Hirn [1992]. (b) Morpho-structural sections crossing the South Coastal Fault Belt, perpendicular to the $\mathrm{N} 140^{\circ} \mathrm{E}$ transverse fault network (see location in Figure 8a). Numbers refer to faults drawn in the structural map in Figure 8a.

felsic bodies of the Ribta Fm. Most of these submeridian fractures were later reactivated as strike-slip faults [Arthaud et al., 1980]. From these structural relationships, the Arta anticline is inferred to have formed as a magma-driven structure overlying a felsic intrusion emplaced during the 3.6 Myr Ribta event.

\subsection{Timing of Faulting in the Tadjoura Rift}

[36] The combination of published and new age determinations on both sedimentary and volcanic rift sequences exposed on the onshore margins of the TR supplies temporal constraints on the sequential development of the Tadjoura half-graben during the last 3 Myr. The Gulf-parallel extensional fault network in the two coastal belts shows a relatively clear age progression depicted on the NS cross-sectional diagram in Figure 10a. As already argued by Manighetti et al. [1997], two successive extensional fault sets are evidenced on the northern flank of the TR, i.e., in the NCFB. The most external faults are postdated by $1.4-0.8 \mathrm{Myr}$ old alluvial fans [Gasse, 1991], while younger similarly trending faults crosscut Holocene conglomerates further south. A quite symmetrical age polarity is documented in the southern margin of the TR, i.e., in the Djibouti Plain, where the oldest tectonic structures are the $\sim 1.7$ Myr old Goumarre tectonomagmatic lineaments transecting the Somali Basalts. Assuming that these linear structures resulted from extrados tensile stress on top of a regional flexure related to the Tadjoura half-graben development suggests a similar age (1.7 Myr) for the onset of faulting along the Tadjoura master fault to the north. The Somali flexure is postdated by onlapping Gulf Basalts (Ambouli section) which are in turn dissected by Gulf-parallel faults, necessarily younger than 1.7 Myr, and older than the $\sim 1$ Myr old Hayyabley volcano which seals them to the west (Figure 10b). However, younger Gulf-parallel faults ( $<1 \mathrm{Myr}$ ), in an inner position, crosscut the northern edge of the Hayyabley volcano. Some of these faults likely extend westward into the Ambaddo area, where they might have caused the north dipping tilt of 140-120 ka old reef limestones [Gasse et al., 1983]. From the crosssectional timing framework in the TR (Figure 10a), it thus appears that the age of faulting increases symmetrically away 

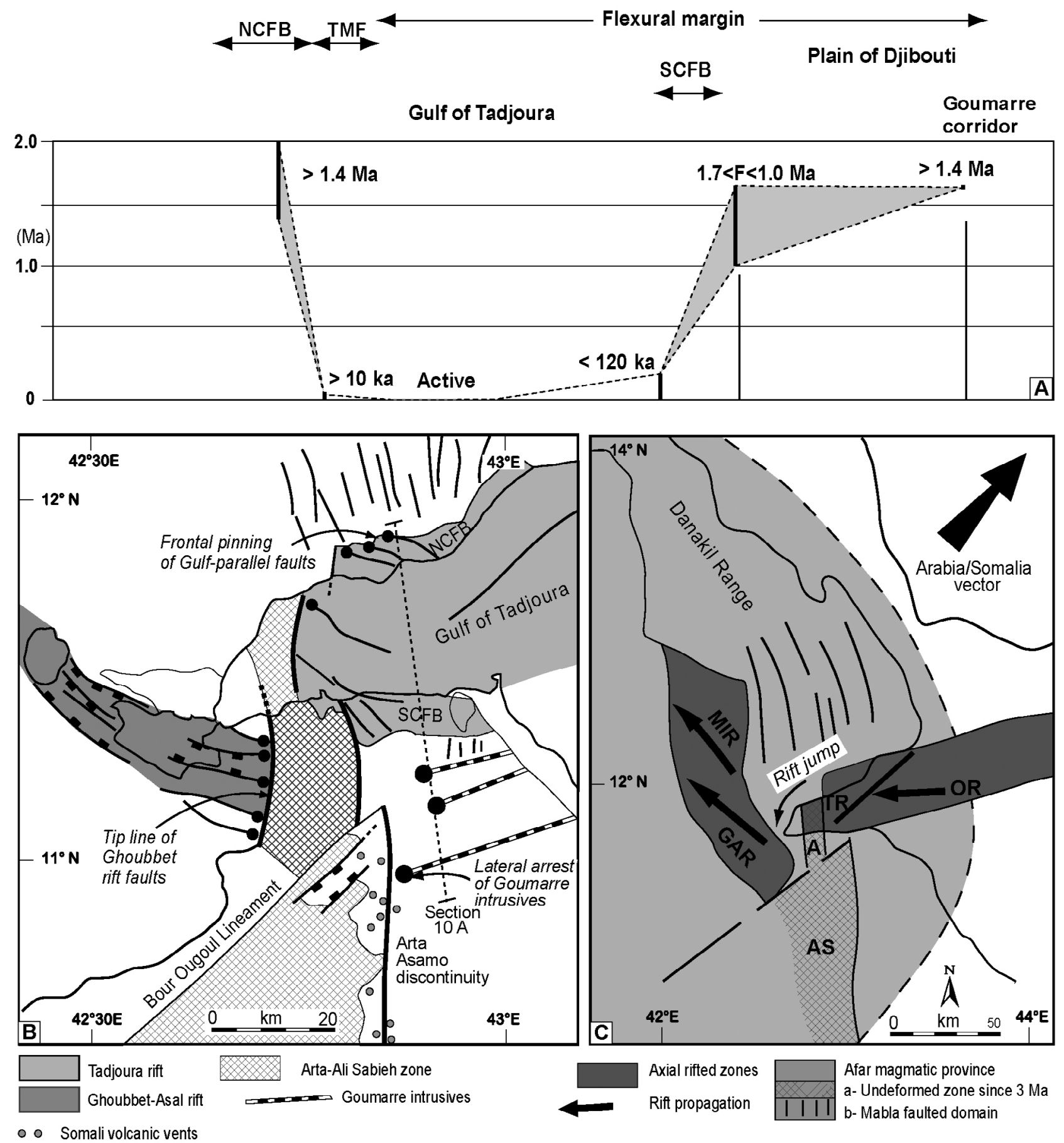

Figure 10. Kinematics of rift propagation throughout the Tadjoura-Ghoubbet connection zone. (a) Timing of faulting along a synthetic cross section of the Tadjoura Rift. Despite age uncertainties, a pattern of younging of strain is observed from the margins to the inner part of the Tadjoura Rift, indicating progressive axial focusing of extension. Abbreviations are: NCFB, Northern Coastal Fault Belt; TMF, Tadjoura master fault; and SCFB, Southern Coastal Fault Belt. (b) Rift kinematic model in the TadjouraGhoubbet linkage zone, emphasizing the role of inherited submeridian structures in pinning the propagation of the Tadjoura and Ghoubbet rifts. (c) Sketch rift pattern showing a major submeridian discontinuity at the transition zone between two variously trending rift arms of the Aden plate boundary. The shaded area corresponds to the eastern edge of the Afar magmatic province (the initial $30 \mathrm{Myr}$ old flood basalts of Yemen are not considered). Abbreviations are: A., Arta zone; AS., Ali Sabieh range; GAR, GhoubbetAsal rift; MIR, Manda-Inakir rift; OR, Obock rift; and TR., Tadjoura rift. 
from the inner rifted zone. The current seismic activity in the offshore part of the TR [Lépine et al., 1980; Hofstetter and Beyth, 2003] fits our proposed age progression of faulting.

\section{Proposed Kinematic Model for the $<3 \mathrm{Myr}$ Rift Evolution of the TR}

[37] In response to the regional $\mathrm{N} 40^{\circ} \mathrm{E}$ extension [Jestin et al., 1994; de Chabalier and Avouac, 1994; Vigny et al., 2007], the TR developed as a $60 \times 40 \mathrm{~km}$ south facing half-graben, filled up by a thick pile of syntectonic fissural Gulf Basalts. In map view, the TR rhomb-shaped structure involves a composite network of dominantly extensional faults, striking EW (Gulf parallel) and NW-SE. The latter trend occurs in the western termination of the TR at the longitude of approximately $42^{\circ} 45^{\prime}$, i.e., in the northern offshore prolongation of the Arta zone. The TR-related faults which exclusively involve the Gulf Basalt-filled halfgraben recorded a complex history within an overall westerly migration of tectonic activity [Manighetti et al., 1997]. The dating of fault-controlled volcanic activity (Goumarre) across the flexural margin of the TR half-graben suggests that the onset of faulting along the master boundary fault to the north occurred at $1.7 \mathrm{Myr}$, concomitantly with active extension in the Tadjoura inner trough. At this stage, the master fault might have developed a number of splays into the footwall uplifted block (NCFB), probably coeval with localized antithetic faulting along part of the flexure to the south (SCFB). The long-lived development of the Tadjoura half-graben was accompanied by the temporal migration from old structures, in an external position, toward younger ones, closer to the Gulf axis. A similar evolution is reported from the Kenya rift, where a temporally progressive focus of strain into a narrow and inner trough has been documented [Baker and Wohlenberg, 1971; Cerling and Powers, 1977; Vétel and Le Gall, 2006]. In addition to cross-rift migration of faulting, along-strike fault propagation also occurred, and resulted in contrasted fault patterns in the NCFB and SCFB. In the NCFB, the amount of displacement decreased regularly westward along Gulf-parallel faults, toward a tip line located within the Gulf Basalts. Very few faults extended beyond the Gulf Basalts/substratum boundary, across the Mabla felsic series (Figure 10b). Small-scale (a few hundreds meters wide) jumping rift segments were assumed to occur in the NCFB [Manighetti et al., 1997], where they turned into a network of en echelon fault swarms which connected the TR and the Ghoubbet rifted trough to the SW These small-scale rift structures are here regarded as subsidiary structures on the northern flank of the TR halfgraben documented in this work.

[38] A more intricate fault pattern is present in the western part of the SCFB. There, the Gulf-parallel extensional faults deviate clockwise, from $\mathrm{N} 90^{\circ} \mathrm{E}$ to $\mathrm{N} 140^{\circ} \mathrm{E}$, when approaching the Arta transverse zone. This fault map curvature is accompanied by a marked increase of fault density westward, together with a decrease of individual fault length, hence resulting in the above mentioned overdisplaced fault pattern.

[39] Several factors are known to control $D / L$, such as (1) strain regime [Gupta and Scholz, 2000], (2) segmenta- tion and linkage [Cartwright et al., 1995], (3) material properties [Bai and Pollard, 2000] and (4) layer thickness [Soliva et al., 2005]. Manighetti et al. [2001] specifically stated that finite slip-length profiles of faults in the Afar region are strongly influenced by the fault propagation history. They also argued that restricted faults $(D / L>0.04)$, resulting from length restriction, formed in response to fault propagation arrest by a "barrier." This barrier might be related to the earlier history of the region. According to this model, the high $D / L$ values $(>0.04)$ obtained here for the westernmost faults in the SCFB likely indicate that their horizontal growth was limited, or even stopped to the west by a mechanical barrier, while these faults continued to accumulate vertical displacement.

[40] Structural data suggest that strong submeridian terranes, including the Arta zone, transect orthogonally the western end of the TR (Figure 10b). To the south, these terranes extend toward the Ali Sabieh anticline [Le Gall et al., 2010]. They are bounded to the east by the so-called Arta-Asamo discontinuity, the $>60 \mathrm{~km}$ long map trace of which is outlined by a variety of structures that indicate its long-lived history. To the north, the decrease of vertical motion along the NW offshore course of the $\mathrm{N} 140^{\circ} \mathrm{E}$ transverse fault network (see Figure 4d) suggests the occurrence of a stronger substratum offshore the Arta zone. The strong mechanical behavior of the Arta transverse zone during recent rifting is also confirmed by (1) the restricted location of earthquakes and aftershocks linked to the 1978 seismic crisis in the Tadjoura gulf [Lépine et al., 1980; Lépine and Hirn, 1992; Doubre, 2004] (Figure 9a), and (2) the abrupt arrest of the EW trending Ghoubbet rift fault network against its NS trending western edge (Figure 10b).

[41] Further south, the continuation of the Arta-Asamo discontinuity along the eastern flank of the Ali Sabieh anticline is deduced from the restricted distribution of the $\mathrm{N} 80^{\circ} \mathrm{E}$ Goumarre fault-dyke corridors which do not penetrate westward into the Ali Sabieh substratum series (Figure 10b). The inherited and deep-seated origin of the Arta-Asamo discontinuity is suggested by the NS alignment of Somali (7.2-3.6 Myr) volcanic vents along its inferred map trace (Figure 10b). This discontinuity might have been guided at depth by a large-scale Proterozoic fracture zone belonging to the Marda system [Boccaletti et al., 1991].

[42] During the recent SE Afar rift history, the Arta preexisting submeridian structures are therefore assumed to have provoked the frontal pinning of axial fault growth in the TR, and then the lateral jump of rifting in the Ghoubbet area, in response to inferred higher strength contrast, together with their orthogonal orientation to rift propagation. This abrupt change in rift kinematics probably occurred at circa $900 \mathrm{ka}$, when diffuse volcanism and associated faulting started in the Asal-Ghoubbet rift [Manighetti et al., 1998; Audin et al., 2001].

\section{Conclusions}

[43] The major and trace element analysis of young basalts collected from onland Tadjoura Rift units (especially from the Djibouti Plain) allows us to distinguish four distinct types, namely the Gulf, Somali, Goumarre and 
Hayyabley Basalts. These results, together with new and previously published radiometric age data, lead us to propose a revised volcano-stratigraphic sketch map of the southern (SCFB) and northern (NCFB) margins of the TR. With respect to former studies [Richard, 1979; Gasse et al., 1983, 1985, 1986], the Goumarre Basalts (2.46-1.69 Myr) are recognized as a distinct unit and the southern limit of the Gulf basalts in the Djibouti Plain is shifted approximately $10 \mathrm{~km}$ northward. A consequence of this revision is that the progressive westerly younging of the Gulf Basalts suggested by previous authors [Richard, 1979; Manighetti et al., 2001; Audin et al., 2004] for the southern and northern borders of the TR is no more supported by the new longitude versus age trends for these basalts.

[44] New structural data based on fieldwork and remote sensing analysis allow us to interpret the overall structure of the TR as an asymmetrical south facing half-graben, about $35 \mathrm{~km}$ wide, dominated by a large boundary fault zone to the north and extending southward as a $>20 \mathrm{~km}$ long shallower flexural margin, partially exposed in the Djibouti Plain. There, it is locally disrupted by an antithetic southern coastal fault belt, and by the Goumarre transverse fault-dike corridors close to the inflexion point of the Somali Basalts monocline. Recent faulting is spatially restricted to the Gulf
Basalts which form two narrow strips on the northern and southern margins of the TR.

[45] The temporal change of the location of normal faults toward the inner trough of the half-graben indicates the progressive focusing of strain with time within the axial part of the rift. The geometrical and statistical analysis of onshore fault networks in the southern fault belt shows a westerly increase of strain that is mechanically assigned to the frontal locking of axial fault tip propagation against submeridian discontinuities in the Arta zone. The arrest of fault propagation in the TR lastly resulted in the jump of rifting into the Ghoubbet-Asal trough system.

[46] Acknowledgments. This study has been funded by the French Embassy in Djibouti, and the grant of the first author (M.A.D.) provided by the MAWARI international program managed by the CIFEG, Orléans, France. Analytical expenses were funded by the MAWARI program and UMR 6538 "Domaines Océaniques," Plouzané. The offshore data reported here were obtained aboard the R/V l'Atalante operated by IFREMER. We especially thank Dr. Mohamed Jalludin, Director of the Centre d'Etudes et de Recherches de Djibouti, for his interest, scientific discussions, and logistic support; Ali Abdillahi for his efficiency in organizing fieldwork logistics; and Joseph Cotton, who performed the geochemical analyses. The detailed and pertinent comments of three anonymous reviewers and the Associate Editor helped us considerably to improve the manuscript and to increase its focus.

\section{References}

Abelson, B. M., and A. Agnon (1997), Mechanics of oblique spreading and ridge segmentation, Earth Planet. Sci. Lett., 148, 405-421, doi:10.1016/ S0012-821X(97)00054-X

Allègre, C. J., M. Treuil, J. F. Minster, B. Minster, and F. Albarède (1977), Systematic use of trace element in igneous processes. Part 1: Fractional crystallization processes in volcanic suites, Contrib. Mineral. Petrol., 60, 57-75, doi:10.1007/BF00372851.

Arthaud, F., and P. Choukroune (1976), Mise en évidence d'une phase de compression à 3, 5 Ma séparant deux épisodes d'ouverture du rift océanique de Tadjoura (T.F.A.I.), C. R. Seances Acad. Sci., Ser. D, 283, 13-16.

Arthaud, F., P. Choukroune, and B. Robineau (1980), Evolution structurale de la zone transformante d'Arta (République de Djibouti), Bull. Soc. Geol. Fr., 22, 909-915.

Audin, L. (1999), Pénétration de la dorsale d'Aden dans la dépression Afar entre 20 et $4 \mathrm{Ma}, \mathrm{Ph}$.D. thesis, Univ. Paris 7, Paris.

Audin, L., I. Manighetti, P. Tapponnier, F. Métivier, E. Jacques, and P. Huchon (2001), Fault propagation and climatic control of sedimentation on the Ghoubbet rift floor: Insights from the Tadjouraden cruise in the western Gulf of Aden, Geophys. $J$ Int., 144, 391-413, doi:10.1046/j.0956-540x. 2000.01322.x

Audin, L., X. Quidelleur, E. Coulié, V. Courtillot, S. Gilder, I. Manighetti, P. Y. Gillot, P. Tapponnier, and T. Kidane (2004), Paleomagnetism and $\mathrm{K}-\mathrm{Ar}$ and ${ }^{40} \mathrm{Ar}{ }^{39} \mathrm{Ar}$ ages in the Ali Sabieh area (Republic of Djibouti and Ethiopia): Constraints on the mechanism of Aden ridge propagation into southeastern Afar during the last $10 \mathrm{Myr}$, Geophys. J. Int., 158(1), 327 345, doi:10.1111/j.1365-246X.2004.02286.x.

Bai, T., and D. D. Pollard (2000), Fracture spacing in layered rocks: A new explanation based on the stress transition, J. Struct. Geol., 22, 43-57, doi:10.1016/S0191-8141(99)00137-6.

Baker, B. H., and J. Wohlenberg (1971), Structure and evolution of the Kenya Rift Valley, Nature, 229, 538-542, doi:10.1038/229538a0.
Barberi, F., G. Ferrara, R. Santacroce, and J. Varet (1975), Structural evolution of the Afar triple junction, in Depression of Ethiopia, vol. 1, edited by A. Pilger and A. Rösler, pp. 38-54, Schweizerbart, Stuttgart, Germany.

Barrat, J. A., B. M. Jahn, J. L. Joron, B. Auvray, and H. Hamdi (1990), Mantle heterogeneity in northeastern Africa: Evidence from $\mathrm{Nd}$ isotopic compositions and hygromagmaphile element geochemistry of basaltic rocks from the Gulf of Tadjoura and Southern Red Sea regions, Earth Planet. Sci. Lett., 101, 233-247, doi:10.1016/0012-821X(90)90156-R

Barrat, J. A., B. M. Jahn, S. Fourcade, and J. L. Joron (1993), Magma genesis in an ongoing rifting zone: The Tadjoura Gulf, Geochim. Cosmochim. Acta, 57, 2291-2302, doi:10.1016/0016-7037(93)90570-M.

Bizouard, H., and O. Richard (1980), Etude de la transition dorsale océanique/rift émergé: Golfe de Tadjoura, Asal, Afar central. Approche pétrographique et minéralogique, Bull. Soc. Geol. Fr., 22, 935-943.

Black, R., W. Morton, and D. C. Rex (1975), Block tilting and volcanism within the Afar in light of recent $\mathrm{K} / \mathrm{Ar}$ date, in Depression of Ethiopia, vol. 1, edited by A. Pilger and A. Rösler, pp. 296-299, Schweizerbart, Stuttgart, Germany.

Boccaletti, M., A. Getaneh, and F. Bonavia (1991), The Marda fault zone: A remnant of an incipient aborted rift in the paleo-African Arabian plate, J. Pet. Geol., 14(1), 79-91, doi:10.1111/j.17475457.1991.tb00300.x

Cartwright, J. A., B. D. Trudgill, and C. Mansfield (1995), Fault growth by segment linkage: An explanation for scatter in maximum displacement and trace length data from the Canyonlands Grabens of SE Utah, J. Struct. Geol., 17(9), 1319-1326, doi:10.1016/0191-8141(95)00033-A.

Cerling, T. E., and D. W. Powers (1977), Paleorifting between the Gregory and Ethiopian rifts, Geology, 5, 441-444, doi:10.1130/0091-7613(1977)5<441: PBTGAE $>2.0 . \mathrm{CO} ; 2$

Chessex, R., M. Delaloye, J. Muller, and M. Weidmann (1975), Evolution of the volcanic region of AliSabieh (T.F.A.I) in the light of K/Ar age determinations, in Depression of Ethiopia, vol. 1, edited by
A. Pilger and A. Rösler, pp. 220-227, Schweizerbart, Stuttgart, Germany.

Cochran, J. R. (1981), The Gulf of Aden: Structure and evolution of a young ocean basin and continental margin, $J$. Geophys, Res., 86, 263-287, doi:10.1029/JB086iB01p00263.

Cotten, J., A. Le Dez, M. Bau, M. Caroff, R. Maury, P. Dulski, S. Fourcade, M. Bohn, and R. Brousse (1995), Origin of anomalous rare-earth element and yttrium enrichments in subaerially exposed basalts: Evidence from French Polynesia, Chem. Geol., 119, 115-138, doi:10.1016/0009-2541(94) 00102-E.

Cowie, P. A., and C. H. Scholz (1992a), Physical explanation for displacement-length relationship for faults using a post-yield fracture mechanics model, J. Struct. Geol., 14, 1133-1148, doi:10.1016/01918141(92)90065-5

Cowie, P. A., and C. H. Scholz (1992b), Displacementlength scaling relationship for faults using a post-yield fracture mechanics model, J. Struct. Geol., 14, 1149 1156, doi:10.1016/0191-8141(92)90066-6.

d'Acremont, E., S. Leroy, M. Maia, P. Patriat, M. O Beslier, N. Bellahsen, M. Fournier, and P. Gente (2006), Structure and evolution of the eastern Gulf of Aden: Insigths from magnetic and gravity data (Encens Sheba Cruise), Geophys. J. Int., 165 786-803, doi:10.1111/j.1365-246X.2006.02950.x.

Daoud, M. A., J. A. Barrat, R. Maury, R. N. Taylor, B. Le Gall, H. Guillou, J. Cotten, and J. Rolet (2010), A LREE-depleted component in the Afar plume: Further evidence from Quaternary Djibouti basalts, Lithos, 114, 327-336, doi:10.1016/j.lithos. 2009.09.008

Dauteuil, O., P. Huchon, F. Quemeneur, and T. Souriot (2001), Propagation of an oblique spreading center: The western Gulf of Aden, Tectonophysics, 332, 423-442, doi:10.1016/S0040-1951(00)00295-X.

Dawers, N. H., M. H. Anders, and C. H. Schloz (1993), Fault length and displacement: Scaling laws, Geology, 21, 1107-1110, doi:10.1130/0091-7613(1993) $021<1107$ :GONFDL $>2.3$.CO;2.

de Chabalier, J. B., and J. P. Avouac (1994), Kinematics of the Asal rift (Djibouti) determined from the 
deformation of Fieale volcano, Science, 265, 16771681, doi:10.1126/science.265.5179.1677.

Deniel, C., P. Vidal, C. Coulon, P. J. Vellutini, and P. Piguet (1994), Temporal evolution of mantle sources during continental rifting: The volcanism of Djibouti (Afar), J. Geophys. Res., 99, 28532869, doi:10.1029/93JB02576.

Doubre, C. (2004), Structure et mécanismes des segments de rift volcano-tectoniques; études de rifts anciens (Ecosse et Islande) et d'un rift actif (AsalGhoubbet), Ph.D. thesis, Univ. du Maine, Le Mans, France.

Fossen, H., and J. Hesthammer (1997), Geometric analysis and scaling relations of deformation bands in porous sandstone, J. Struct. Geol., 19, 1479-1493, doi:10.1016/S0191-8141(97)00075-8.

Fournier, M., et al. (2010), Arabia-Somalia plate kinematics, evolution of the Aden-Owen-Carlsberg triple junction, and opening of the Gulf of Aden, J. Geophys. Res., 115, B04102, doi:10.1029/ 2008 JB006257.

Furman, T., J. Bryce, T. Rooney, B. Hana, G. Yirgu, and D. Ayalew (2006), Heads and tails: 30 million years of the Afar plume, Geol. Soc. Spec. Publ., 259, 95-119, doi:10.1144/GSL.SP.2006.259.01.09.

Gasse, F. (1991), Tectonic and climatic controls on lake distribution and environments in Afar from Miocene to present, in Lacustrine Basin Exploration: Case Studies and Modern Analogs, Am. Assoc. Petrol. Geol. Mem., vol. 50, edited by B. Katz, pp. 19-41, Am. Assoc. Petrol. Geol., Tulsa, Okla.

Gasse, F., M. Fournier, and O. Richard (1983), Carte géologique de la République de Djibouti à 1:100000, Djibouti, notice explicative, ISERST, Ministère français de la Coopération, Paris.

Gasse, F., M. Fournier, O. Richard, and J. C. Ruegg (1985), Carte géologique de la République de Djibouti à 1:100000, Tadjoura, notice explicative, ISERST, Ministère français de la Coopération, Paris.

Gasse, F., J. Varet, G. Mazet, F. Recroix, and J. C. Ruegg (1986), Carte géologique de la République de Djibouti à 1:100000, Ali Sabieh, notice explicative, ISERST, Ministère français de la Coopération, Paris.

Gaulier, J. M., and P. Huchon (1991), Tectonic evolution of Afar triple junction, Bull. Soc. Geol. Fr., $162,451-464$

Gillespie, P. A., J. J. Walsh, and J. Watterson (1992), Limitation of dimension and displacement data from single fault and the consequences for data analysis and interpretation, J. Struct. Geol., 14, 1157-1172, doi:10.1016/0191-8141(92)90067-7.

Guillou, H., B. Singer, C. Laj, C. Kissel, S. Scaillet, and B. R. Jicha (2004), On the age of the Laschamp geomagnetic event, Earth Planet. Sci. Lett., 227 , 331-343, doi:10.1016/j.eps1.2004.09.018.

Gupta, A., and C. Scholz (2000), Brittle strain regime transition in the Afar depression: Implications for fault growth and seafloor spreading, Geology, 28, 1087-1090, doi:10.1130/0091-7613(2000) $28<1087$ :BSRTIT $>2.0$. CO;2.

Hofstetter, R., and M. Beyth (2003), The Afar Depression: Interpretation of the 1960-2000 earthquakes, Geophys. J. Int., 155, 715-732, doi:10.1046/ j.1365-246X.2003.02080.x.

Irvine, T. N., and W. R. A. Baragar (1971), A guide to the chemical classification of the common rocks, Can. J. Earth Sci., 8, 523-548.

Jestin, F., P. Huchon, and J. M. Gaulier (1994), The Somalia plate and the East African Rift System: Present kinematics, Geophys. J. Int., 116, 637654, doi:10.1111/j.1365-246X.1994.tb03286.x.

Joron, J. L., M. Treuil, H. Jaffrezic, B. Villemant, and O. Richard (1980a), Géochimie des éléments en traces du volcanisme de l'Afar et de la mégastruc- ture Mer Rouge-Afar-Golfe d'Aden. Implications pétrogénétiques et géodynamiques, Bull. Soc. Geol. Fr., 22, 945-957.

Joron, J. L., M. Treuil, H. Jaffrezic, and B. Villemant (1980b), Etude géochimique des éléments en traces dans les séries de roches volcaniques du rift d'Asal. Identification et analyse des processus d'accrétion, Bull. Soc. Geol. Fr., 22, 851-861.

Le Bas, M., R. Le Maitre, A. Streckeisen, and B. Zanettin (1986), A chemical classification of volcanics rocks based on total alkalin-silica diagram, J. Petrol., 27 (3), 745-750

Le Gall, B., M. A. Daoud, J. Rolet, R. C. Maury, H. Guillou, and C. Sue (2010), Magma-driven antiform structures in the Afar rift: The Ali Sabieh range, Djibouti, J. Struct. Geol., 32, 843-854, doi:10.1016/j.jsg.2010.06.007.

Lépine, J. C., and A. Hirn (1992), Seismotectonics in the Republic of Djibouti, linking the Afar Depression and the Gulf of Aden, Tectonophysics, 209 65-86, doi:10.1016/0040-1951(92)90011-T.

Lépine, J. C., J. C. Ruegg, and A. M. Anis (1980), Sismicité du rift d'Asal-Ghoubbet pendant la crise sismo-volcanique de novembre 1978, Bull. Soc. Geol. Fr., 22, 809-816.

Leroy, S., et al. (2004), From rifting to drifting in the eastern Gulf of Aden: A complete margin survey coverage of a young oceanic basin from margin to margin, Terra Nova, 16, 185-192, doi:10.1111/ j.1365-3121.2004.00550.x.

Manighetti, I., P. Tapponnier, V. Courtillot, S. Gruszow, and P. Y. Gillot (1997), Propagation of rifting along the Arabia-Somalia plate boundary: The Gulf of Aden and Tadjoura, J. Geophys. Res., 102, 26812710, doi:10.1029/96JB01185.

Manighetti, I., P. Tapponnier, P. Y. Gillot, E. Jacques, V. Courtillot, R. Armijo, J. C. Ruegg, and G. King (1998), Propagation of rifting along the ArabiaSomalia plate boundary into Afar, J. Geophys. Res., 103, 4947-4974, doi:10.1029/97JB02758.

Manighetti, I., G. C. P. King, Y. Gaudemer, C. Scholz, and C. Doubre (2001), Slip accumulation and lateral propagation of active normal faults in Afar, J. Geophys. Res., 13, 667-696.

Marinelli, G., and J. Varet (1973), Structure et évolution du Sud "Horst Danakil", C. R. Seances Acad. Sci., Ser. D, 276, 1119-1122.

Richard, O. (1979), Etude de la transition dorsale océanique-rift émergé: Le Golfe de Tadjoura (République de Djibouti). Approche géologique, géochronologique et pétrologique, Ph.D. thesis, 149 pp., Univ. Paris XI-Orsay, Paris, France.

Rogers, N. W. (2006), Basaltic magmatism and the geodynamics of the East African Rift System, Geol. Soc. Spec. Pub., 259, 77-93, doi:10.1144/GSL. SP.2006.259.01.08

Ruegg, J. C., J. C. Lépine, and C. Vincent (1980), Sismicité et micro-sismicité de la dorsale de Tadjoura, tectonique et frontière de plaques, Bull. Soc. Geol. Fr., 22, 917-923.

Schlische, R. W., S. S. Young, R. V. Ackermann, and A. Gupta (1996), Geometry and scaling relations of a population of very small rift-related norma faults, Geology, 24, 683-686, doi:10.1130/00917613(1996)024<0683:GASROA $>2.3 . \mathrm{CO} ; 2$

Soliva, R., R. A. Schultz, and A. Benedicto (2005), Three-dimensional displacement-length scaling and maximum dimension of normal faults in layered rocks, Geophys. Res. Lett., 32, L16302, doi:10.1029/2005GL023007.

Steiger, R. H., and E. Jäger (1977), Subcommission on geochronology: Convention on the use of decay constants in geo- and cosmochronology, Earth Planet. Sci. Lett., 36, 359-362, doi:10.1016/0012 $821 \mathrm{X}(77) 90060-7$
Sun, S. S., and W. F. McDonough (1989), Chemical and isotopic systematics of oceanic basalts: Implications for mantle composition and processes, Geol. Soc. Spec. Publ., 42, 313-345, doi:10.1144/GSL. SP.1989.042.01.19.

Tamsett, D., and R. C. Searle (1988), Structure and development of the midocean ridge plate boundary in the Gulf of Aden: Evidence from GLORIA sidescan sonar, J. Geophys. Res., 93, 3157-3178, doi:10.1029/JB093iB04p03157.

Trudgill, B. D., and J. A. Cartwright (1994), Relay ramp morphology and normal fault linkages, Canyonland National Park, Utah, Geol. Soc. Am. Bull., 106, 1143-1157, doi:10.1130/0016-7606 (1994) 106<1143:RRFANF $>2.3 . C O ; 2$

Vétel, W., and B. Le Gall (2006), Dynamics of prolonged continental extension in magmatic rifts: The Turkana Rift case study (North Kenya), Geol. Soc. Spec. Publ., 259, 209-233, doi:10.1144/GSL. SP.2006.259.01.17.

Vidal, P., C. Deniel, P. J. Vellutini, P. Piguet, C. Coulon, J. Vincent, and L. Audin (1991), Changes of mantle sources in the course of a rift evolution: The Afar case, Geophys. Res. Lett., 18, 1913-1916, doi:10.1029/91GL02006.

Vigny, C., J. B. de Chabalier, J. C. Ruegg, P. Huchon, K. Feigl, R. Cattin, L. Asfaw, and K. Khanbari (2007), Twenty-five years of geodetic measurements along the Tadjoura-Asal rift system, Djibouti, East Africa, J. Geophys. Res., 112, B06410, doi:10.1029/2004JB003230.

Walsh, J. J., and J. Watterson (1988), Analysis of relationship between displacement and dimensions of faults, J. Struct. Geol., 10, 239-247, doi:10.1016/ 0191-8141(88)90057-0.

Watterson, J. (1986), Fault dimensions, displacement and growth, Pure Appl. Geophys., 124, 365-373, doi:10.1007/BF00875732.

Wijns, C., R. Weinberg, K. Gessner, and L. Moresi (2005), Mode of crustal extension determined by rheological layering, Earth Planet. Sci. Lett., 236 , 120-134, doi:10.1016/j.eps1.2005.05.030.

Wojtal, S. F. (1994), Fault scaling laws and the temporal evolution of fault systems, J. Struct. Geol., 16, 603-612, doi:10.1016/0191-8141(94)90100-7.

Yurtmen, S., H. Guillou, O. Orhan, G. Rowbotham, and R. Westaway (2002), Rate of strike-slip on the Amanos Fault (Karasu Valley, southern Turkey) constrained by $\mathrm{K}-\mathrm{Ar}$ dating and geochemical analysis of Quaternary basalts, Tectonophysics, 344, 207-246, doi:10.1016/S0040-1951(01)00265-7.

Ziegler, P. A., and S. Cloetingh (2004), Dynamic processes controlling evolution of rifted basins, Earth Sci. Rev., 64, 1-50, doi:10.1016/S0012-8252(03) 00041-2.

Zumbo, V., G. Féraud, H. Vellutini, P. Piguet, and J. Vincent (1995), First ${ }^{40} \mathrm{Ar} /{ }^{39} \mathrm{Ar}$ datings on Early Pliocene to Plio-Pleistocene magmatic events of the Afar-Republic of Djibouti, J. Volcanol. Geotherm. Res., 65, 281-295, doi:10.1016/03770273(94)00107-R.

M. A. Daoud, Institut des Sciences de la Terre, Centre d'Études et de Recherches de Djibouti, B.P. 486, Djibouti Ville, Djibouti. (adm_876@yahoo.fr)

H. Guillou, UMR 1572, LSCE/CEA-CNRS, Domaine du CNRS, 12 Avenue de la Terrasse, F-91118 Gif-sur-Yvette, France.

P. Huchon, UPMC Université de Paris 6, CNRS, UMR 7193, ISTeP, 4 Place Jussieu, F-75252 Paris Cedex 05, France.

B. Le Gall, R. C. Maury, and J. Rolet, Université Européenne de Bretagne, Université de Brest, CNRS, UMR 6538 Domaines Océaniques, IUEM, Place N. Copernic, F-29280 Plouzané, France. 